\title{
1 Prediction of micropollutant elimination during ozonation of a hospital
}

2

3

4

5

$6 \quad{ }^{1}$ Eawag, Swiss Federal Institute of Aquatic Science and Technology, Ueberlandstrasse 133, CH-8600

7 Duebendorf, Switzerland

8

9

10

11

12

13

14

15

16

17

18

19

20

21

22

23

\section{wastewater effluent}

${ }^{2}$ Department of Environmental Science and Engineering, Gwangju Institute of Science and

Technology (GIST), Gwangju 500-712, Republic of Korea

${ }^{3}$ Institute of Biogeochemistry and Pollutant Dynamics, ETH Zurich, CH-8092 Zurich, Switzerland

${ }^{4}$ School of Architecture, Civil and Environmental Engineering (ENAC), Ecole Polytechnique Fédérale de Lausanne (EPFL), CH-1015, Lausanne, Switzerland

*Corresponding authors:

Christa S. McArdell, phone: +41-58-7655483, fax: +41-58-7655028, e-mail: christa.mcardell@eawag.ch

Urs von Gunten, phone: +41-58-7655270, fax: +41-58-7655210, e-mail: vongunten@eawag.ch

This accepted manuscript is made available under the CC-BY-NC-ND 4.0 1icense http://creativecommons.org/1icences/by-nc-nd/4.0/

This document is the accepted manuscript version of the following article: Lee, Y., Kovalova, L., McArde11, C. S., \& Von Gunten, U. (2014). Prediction of micropollutant elimination during ozonation of a hospital wastewater effluent. Water Research, 64, 134-148. http://doi.org/10.1016/j.watres.2014.06.027 


\section{Abstract}

25 Determining optimal ozone doses for organic micropollutant elimination during wastewater ozonation is challenged by the presence of a large number of structurally diverse micropollutants for varying wastewater matrices compositions. A chemical kinetics approach based on ozone and hydroxyl radical $\left({ }^{\circ} \mathrm{OH}\right)$ rate constant and measurements of ozone and ${ }^{\circ} \mathrm{OH}$ exposures is proposed to predict the micropollutant elimination efficiency. To further test and validate the chemical kinetics approach, the elimination efficiency of 25 micropollutants present in a hospital wastewater effluent from a pilot-scale membrane bioreactor (MBR) were determined at $\mathrm{pH} 7.0$ and 8.5 in bench-scale experiments with ozone alone and ozone combined with $\mathrm{H}_{2} \mathrm{O}_{2}$ as a function of DOC-normalized specific ozone dose $\left(\mathrm{gO}_{3} / \mathrm{gDOC}\right)$. Furthermore, ozone and ${ }^{\circ} \mathrm{OH}$ exposures, ${ }^{\circ} \mathrm{OH}$ yields, and ${ }^{\bullet} \mathrm{OH}$ consumption rates were determined. Consistent eliminations as a function of $\mathrm{gO}_{3} / \mathrm{gDOC}$ were observed for micropollutants with similar ozone and ${ }^{\circ} \mathrm{OH}$ rate constants. They could be classified into five groups having characteristic elimination patterns. By increasing the $\mathrm{pH}$ from 7.0 to 8.5 , the elimination levels increased for the amine-containing micropollutants due to the increased apparent second-order ozone rate constants while decreased for most micropollutants due to the diminished ozone or ${ }^{\bullet} \mathrm{OH}$ exposures. Increased ${ }^{\bullet} \mathrm{OH}$ quenching by effluent organic matter and carbonate with increasing $\mathrm{pH}$ was responsible for the lower ${ }^{\bullet} \mathrm{OH}$ exposures. Upon $\mathrm{H}_{2} \mathrm{O}_{2}$ addition, the elimination levels of the micropollutants slightly increased at $\mathrm{pH} 7(<8 \%)$ while decreased considerably at $\mathrm{pH}$ 8.5 (up to $31 \%$ ). The elimination efficiencies of the selected micropollutants could be predicted based on their ozone and ${ }^{\circ} \mathrm{OH}$ rate constants (predicted or taken from literature) and the determined ozone and ${ }^{\circ} \mathrm{OH}$ exposures. Reasonable agreements between the measured and predicted elimination levels were found, demonstrating that the proposed chemical kinetics method can be used for a generalized prediction of micropollutant elimination during wastewater ozonation. Out of 67 
analyzed micropollutants, 56 were present in the tested hospital wastewater effluent. Two-thirds of the present micropollutants were found to be ozone-reactive and efficiently eliminated at low ozone doses (e.g., $>80 \%$ for $\mathrm{gO}_{3} / \mathrm{gDOC}=0.5$ ).

Keywords: ozonation, advanced oxidation process, micropollutant, pharmaceutical, hospital wastewater, QSAR

\section{Introduction}

In recent years, ozonation has been intensively tested as an advanced wastewater treatment technology from laboratory- to full-scale studies and demonstrated to be a useful, economically feasible method to improve the quality of municipal wastewater effluents (Flyborg et al., 2010; Gerrity et al., 2011 \& 2012; Hollender et al., 2009; Huber et al., 2005; Lee et al., 2013; Margot et al., 2013; Nakada et al., 2007; Reungoat et al., 2012; von Sonntag and von Gunten, 2012; Zimmermann et al., 2011). These studies have shown that ozonation of secondary wastewater effluents can achieve significant abatement of many organic micropollutants and inactivation of bacteria and viruses at reasonable specific ozone doses (e.g., $\mathrm{gO}_{3} / \mathrm{gDOC}=0.5-1.0$ in which the mass-based ozone to dissolved organic carbon ratio is a common operating parameter for ozone applications). Significant reductions of in vitro and in vivo toxicities were also demonstrated after ozonation or ozonation followed by biological filtration (Escher et al., 2009; Macova et al., 2010; Reungoat et al., 2012; Stalter et al., 2010a \& 2010b).

The presence of a large number of structurally diverse micropollutants in wastewater matrices from various sources has been found to be challenging for ozonation process design for 
micropollutant elimination (Lee et al., 2013). The number of organic micropollutants in wastewaters

71 is up to several hundred (Oulton et al., 2010), which makes it cost-prohibitive and impractical to

72

73

74

75

measure their elimination efficiencies individually. Wastewater quality parameters such as effluent organic matter (EfOM) or $\mathrm{pH}$ can vary considerably depending on the wastewater sources or operating conditions of wastewater treatment plants. EfOM is the main sink for ozone and $\mathrm{OH}$ radicals $\left({ }^{\circ} \mathrm{OH}\right)$, thus it has been difficult to predict the micropollutant elimination efficiency in wastewater effluents containing EfOMs with different concentration and characteristics.

A previous study showed that these challenges can be solved using an approach based on chemical kinetics (Lee et al., 2013). The elimination of a micropollutant (P) during ozonation is achieved by its reaction with ozone and ${ }^{\bullet} \mathrm{OH}$, the latter is produced from the ozone decomposition (von Sonntag and von Gunten, 2012). The elimination of P in terms of logarithmic relative residual concentration of $\mathrm{P}$ can be predicted if the ozone and ${ }^{\circ} \mathrm{OH}$ rate constant (i.e., $k_{\mathrm{O} 3}$ and $k_{\bullet} \mathrm{OH}$ ) and the ozone and ${ }^{\bullet} \mathrm{OH}$ exposures $\left(\int\left[\mathrm{O}_{3}\right] \mathrm{dt}\right.$ and $\left.\int\left[{ }^{\bullet} \mathrm{OH}\right] \mathrm{dt}\right)$ are known (eq 1).

$$
-\ln \left(\frac{[\mathrm{P}]}{[\mathrm{P}]_{0}}\right)=k_{\mathrm{O} 3} \int\left[\mathrm{O}_{3}\right] \mathrm{dt}+k_{\bullet} \mathrm{OH} \int\left[\bullet^{\bullet} \mathrm{OH}\right] \mathrm{dt}
$$

Ozone reacts selectively with compounds containing electron-rich moieties (ERMs), such as phenols, anilines, activated aromatics, amines, organic sulfurs, and olefins with $k_{\mathrm{O} 3}$-values typically ranging from $10^{3}-10^{7} \mathrm{M}^{-1} \mathrm{~s}^{-1}$ at $\mathrm{pH} 7$ (Lee and von Gunten, 2010). Quantitative structure-activity relationships (QSARs) have been found between the logarithmic $k_{\mathrm{O} 3}$-values for the ozone reactions with compounds having a common ERM vs. Hammett or Taft sigma constants as substituent descriptor variables. These QSARs were found to be able to predict the $k_{03}$-values for various organic compounds within a factor of $1 / 3-3$ compared to measured values (Lee and von Gunten, 2012). ${ }^{\bullet} \mathrm{OH}$ is a less selective oxidant with $k_{\bullet} \mathrm{OH}^{-v a l u e s}$ generally differing within only a factor of 3 for most organic compounds $\left(k_{\bullet \mathrm{OH}}=3 \times 10^{9}-10^{10} \mathrm{M}^{-1} \mathrm{~s}^{-1}\right.$, Buxton et al., 1988; NDRL/NIST Solution 
93 Kinetic Database, http://kinetics.nist.gov/solution/). A group contribution method has been

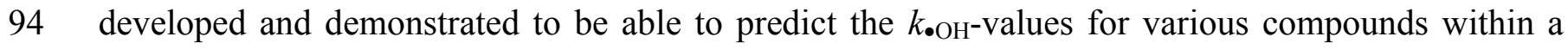

95 factor of 1/2 - 2 compared to measured values (Minakata et al., 2009). Based on eq 1, ozone-reactive

96 micropollutants with ERMs can be more efficiently eliminated than ozone-resistant ones without

97 ERMs due to the combined reaction with ozone and ${ }^{\bullet} \mathrm{OH}$.

98 It was shown previously that similar ${ }^{\bullet} \mathrm{OH}$ exposures were achieved at the same specific ozone 99 dose (i.e., $\mathrm{gO}_{3} / \mathrm{gDOC}$ ) during ozonation of 10 municipal wastewater effluents from Australia,

100 Switzerland, and the USA regardless of water qualities (Lee et al., 2013). Variations of the ozone 101 exposures for the same $\mathrm{gO}_{3} / \mathrm{gDOC}$ were within a factor of 4 and were larger than the variations of

102 the ${ }^{\bullet} \mathrm{OH}$ exposures that were within a factor of 2 . Nevertheless, the large variations of the ozone 103 exposure affected only the elimination efficiency of ozone-reactive micropollutants with elimination

104 levels already close to the quantification limits (e.g., >95\% elimination) for low ozone doses (e.g., $\left.105 \mathrm{gO}_{3} / \mathrm{gDOC}<0.5\right)$. Overall, it was concluded that the elimination of micropollutants having the same 106 or similar $k_{\mathrm{O}^{3}}$ and $k_{\bullet \mathrm{OH}^{-}}$-values was comparable at the same specific ozone dose $\left(\mathrm{gO}_{3} / \mathrm{gDOC}\right)$ during 107 ozonation of wastewater effluents (Lee et al., 2013). Therefore, the specific ozone dose, and the $k_{\mathrm{O}^{-}}$ 108 and $k_{\cdot \mathrm{OH}^{-}}$-values were identified as the key parameters to predict and generalize the elimination 109 efficiency of micropollutants during ozonation of municipal wastewater effluent. To further test, 110 validate, and upgrade the afore-described chemical kinetics approach, more measurements of the 111 ozone and ${ }^{\circ} \mathrm{OH}$ exposures in wastewater effluents with a range of matrix characteristics are 112 recommended considering the still limited information for these parameters. Studies for comparing 113 the measured and predicted elimination of micropollutants covering a broader range of chemical 114 structure are also needed. 
${ }^{\bullet} \mathrm{OH}$ exposure during ozonation has been determined indirectly from the decrease of ${ }^{\bullet} \mathrm{OH}-$ probe

116 compounds (ozone-resistant, $k_{\mathrm{O} 3}<1 \mathrm{M}^{-1} \mathrm{~s}^{-1}$ ) and using eq 1. Para-chlorobenzoic acid ( $\left.p \mathrm{CBA}\right)$ has

117 been widely used as an ${ }^{\bullet} \mathrm{OH}-$ probe compound that has to be spiked to test samples before ozonation

118 (von Gunten and von Sonntag, 2012). Any ozone-resistant micropollutants originally present in test

119 samples can also be used as an ${ }^{\circ} \mathrm{OH}-$ probe compound. Direct measurements of the ozone exposure

120 from the ozone decay curves are difficult in wastewater effluents due to the rapid ozone consumption

121 especially for $\mathrm{gO}_{3} / \mathrm{gDOC}<0.5$ (Lee et al., 2013). The ozone exposure can also be indirectly

122 determined from a decrease of ozone-probe (or ozone-reactive) compounds and using eq 1 after

123 correcting the elimination of the ozone-probe compound by ${ }^{\bullet} \mathrm{OH}$. However, the prediction of the

124 elimination for micropollutants based on the ozone exposures determined by the indirect method was

125 not successful in laboratory- or pilot-scale wastewater ozonation experiments (Huber et al. 2005;

126 Hübner et al., 2013).

127 Hospital wastewaters contain various pharmaceuticals and disinfectants in high concentrations

128 (Kovalova et al., 2012; Kovalova et al., 2013; Ort et al., 2010; Weissbrodt et al, 2009). They also

129 contain pathogens and antibiotic resistant bacteria, which are of considerable public health concern

130 (Blanch et al., 2003; Reinthaler et al., 2003). Separate treatment of hospital wastewater at the source

131 has been thus proposed and tested as it avoids dilution of such contaminants of concern due to

132 mixing with the municipal wastewaters and minimize their losses into the environment via sewer

133 leaks and overflows (Kovalova et al., 2012 \& 2013; Verlicchi et al., 2010). Membrane bioreactors

134 (MBRs) have been shown to be a promising technology for separate treatment of hospital

135 wastewaters due to their high removal efficiency of microorganisms, efficient nutrient removal, and

136 small system footprint (Beier et al., 2011; Kovalova et al., 2012; Mahnik et al., 2007). Nevertheless,

137 to achieve sufficient micropollutant elimination, additional treatment steps beyond the biological 
138 treatment process were required such as ozonation or powered activated carbon (PAC) addition

139 (Kovalova et al., 2013; Oulton et al., 2010). EfOM characteristics of the MBR permeate can differ

140 from those from conventional activated sludge because larger biopolymers (e.g., $>10 \mathrm{kDa})$ can be

141 removed by ultrafiltration in the MBR (see Supporting Information, Figure S1). Considering these

142 characteristics of hospital wastewater effluents treated by MBR (i.e., larger number of structurally

143 diverse micropollutants and smaller average size of EfOM), they are a good candidate to test the

144 chemical kinetics approach for predicting micropollutant elimination during ozonation.

145 To test and validate the chemical kinetics approach for micropollutant elimination prediction, a

146 hospital wastewater effluent from a pilot-scale MBR was selected and treated in a bench-scale with

147 ozone alone and the $\mathrm{O}_{3} / \mathrm{H}_{2} \mathrm{O}_{2}$ advanced oxidation process (AOP) for various specific ozone doses

$148\left(\mathrm{gO}_{3} / \mathrm{gDOC}\right)$. The $\mathrm{pH}$ was set to 7.0 and 8.5 to test the $\mathrm{pH}$-effect in a typical $\mathrm{pH}$-range of municipal

149 wastewater effluents. The elimination levels of 25 micropollutants originally present in the

150 wastewater effluent at concentrations $>0.1 \mu \mathrm{g} / \mathrm{L}$ were quantified after each treatment and compared

151 with the model predictions. The $k_{\mathrm{O}^{-}}$and $k_{\bullet \mathrm{OH}^{-}}$-values for the selected micropollutants were taken

152 from literature or estimated using a QSAR approach (Lee et al., 2012) and the group contribution

153 method (Minakata et al., 2009), respectively, when not available. In addition, the ozone and ${ }^{\circ} \mathrm{OH}$

154 exposures as a function of $\mathrm{gO}_{3} / \mathrm{gDOC}$ were measured based on the elimination of ozone- and ${ }^{\circ} \mathrm{OH}$ -

155 probe compounds. The ${ }^{\bullet} \mathrm{OH}$ yield and the ${ }^{\circ} \mathrm{OH}$ reaction rate constant with EfOM were also

156 determined. Elimination levels for 33 additional micropollutants detected in the tested hospital

157 wastewater effluent were predicted using the same kinetic approach. Finally, the formation of

158 bromate after ozonation was assessed.

159

160 


\section{Materials and Methods}

162

163

164

165

166

\subsection{Standards and reagents}

All chemicals and solvents (95\% purity or higher) were used as received from various commercial suppliers. Ozone stock solutions $(1-1.5 \mathrm{mM})$ were produced by sparging ozone containing oxygen gas through deionized water that was cooled in an ice bath. An ozone generator from Innovatec, Rheinbach (model CMG 3-3, Germany) was used. Stock solutions of hydrogen peroxide $(10 \mathrm{mM})$ were prepared by diluting a $\sim 30 \% \mathrm{H}_{2} \mathrm{O}_{2}$ solution from Sigma-Aldrich. Ozone and $\mathrm{H}_{2} \mathrm{O}_{2}$ stock solutions were standardized spectrophotometrically based on their molar absorption coefficients: $\varepsilon=3000 \mathrm{M}^{-1} \mathrm{~cm}^{-1}$ at $258 \mathrm{~nm}$ (Huber et al., 2003) and $\varepsilon=40 \mathrm{M}^{-1} \mathrm{~cm}^{-1}$ at $240 \mathrm{~nm}$ for $\mathrm{H}_{2} \mathrm{O}_{2}$ (Bader et al., 1998).

\subsection{Hospital wastewater effluents}

Hospital wastewater effluents were taken as composite samples (24 hrs) from a pilot membrane bioreactor (MBR) installed at the cantonal hospital in Baden, Switzerland. The MBR was operating continuously for one year from April 2009 to March 2010 to treat $0.5 \%$ of the hospital wastewater $\left(1.2 \mathrm{~m}^{3}\right.$ per day) taken flow-proportionally from the hospital sewer collection system. Water quality parameters of the MBR permeate used for ozonation experiments were: $\mathrm{DOC}=5.1 \mathrm{mgC} / \mathrm{L}, \mathrm{pH}=8.5$, alkalinity $=7.7 \mathrm{mM}$ as $\mathrm{HCO}_{3}^{-}, \mathrm{NH}_{4}^{+}=<6 \mu \mathrm{gN} / \mathrm{L}, \mathrm{NO}_{2}^{-}=1 \mu \mathrm{gN} / \mathrm{L}, \mathrm{NO}_{3}{ }^{-}=4.2 \mathrm{mgN} / \mathrm{L}$, and $\mathrm{Br}^{-}=$ $32 \mu \mathrm{g} / \mathrm{L}$. The $\mathrm{pH}$ of the wastewater effluent during the MBR operation was $8.1-8.5$. Further details of the MBR pilot plant can be found elsewhere (Kovalova et al., 2012).

\subsection{Ozonation of wastewater effluent}


The sampled hospital wastewater effluent (i.e., MBR permeate) was analysed for the presence of

18467 target micropollutants including pharmaceuticals, their metabolites, and corrosion inhibitors (SI,

185 Tables S1 and S2). Among these target micropollutants, 25 compounds (Table 1) were selected for 186 assessing their elimination efficiency during ozonation. The ambient concentration of the 25

187 compounds were $>0.1 \mu \mathrm{g} / \mathrm{L}$ except bezafibrate (Figure S2). As the elimination behaviour of 188 bezafibrate as an ozone-probe compound was important in this study, it was spiked to the wastewater 189 effluent to achieve $1.6 \mu \mathrm{g} / \mathrm{L}$. Elimination of the remaining 42 compounds could not be determined 190 because their concentrations were below the method quantification limit, or were too low to 191 determine elimination levels $>50 \%$, or the uncertainty of the analytical method was too high.

192 Ozonation was performed in bench-scale using the wastewater effluent at $\mathrm{pH} 8.5$ (original) and at $193 \mathrm{pH} 7.0$ (adjusted by adding $\left.\mathrm{H}_{2} \mathrm{SO}_{4}\right)$ and at a range of specific ozone doses $\left(\mathrm{gO}_{3} / \mathrm{gDOC}=0.25,0.5\right.$, 194 1.0, and 1.5) and hydrogen peroxide doses (molar ratio $\mathrm{H}_{2} \mathrm{O}_{2} / \mathrm{O}_{3}=0,0.25$, and 0.5 ) at room 195 temperature $\left(22 \pm 2^{\circ} \mathrm{C}\right)$. Aliquots of ozone stock solutions were added under vigorous stirring to a 196 series of identical reaction solutions $(500 \mathrm{~mL})$. For ozone/hydrogen peroxide experiments, stock 197 solutions of hydrogen peroxide were added before the ozone addition. In experiments for the 198 elimination of the indicator compounds (i.e., carbamazepine, bezafibrate, and para-chlorobenzoic 199 acid $(p \mathrm{CBA})$ ), these compounds were spiked at $1 \mu \mathrm{M}$ (a few hundreds $\mu \mathrm{g} / \mathrm{L}$ ) and then ozonated in a $20025 \mathrm{~mL}$ reaction flask. After several hours (note that ozone decay was completed within $0.5 \mathrm{~h}$ ), all 201 ozonated samples were stored at $4{ }^{\circ} \mathrm{C}$ prior to analysis of residual micropollutant concentrations. 202 Bromide and bromate were also analysed for these samples. All ozonation experiments were 203 performed in duplicate and average values are used. Description of further details of the bench-scale 204 ozone experiments can be found elsewhere (Lee et al., 2013). 


\subsection{Prediction of ozone and ${ }^{\bullet} \mathrm{OH}$ rate constants}

207 Among the 56 micropollutants detected in the hospital wastewater effluent, the $k_{\mathrm{O}^{-}}{ }^{-}$or $k_{\bullet} \mathrm{OH}^{-}$ 208 values were not available for 39 micropollutants (see Table S2). These rate constants were predicted 209 in this study using a QSAR approach (Lee and von Gunten, 2012) and the group contribution method 210 (Minakata et al., 2009), respectively. The following QSARs were used to estimate $k_{03}$-values: $211 \log \left(\mathrm{k}_{\mathrm{amine}}\right)=6.13-1.00 \sum \sigma^{*}$ for amines such as lidocaine, ranitidine, sotalol, atenolol-acid, 212 venlafaxine, and gabapentin; $\log \left(\mathrm{k}_{\mathrm{BZD}}\right)=-0.04-3.35 \Sigma \sigma_{\mathrm{p}}^{+}$for benzene derivatives such as 213 furosemide, lidocaine, and sotalol; $\log \left(k_{\mathrm{ArNH} 2}\right)=7.15-1.54 \Sigma \sigma_{\mathrm{o}, \mathrm{m}, \mathrm{p}}^{-}$for anilines such as furosemide 214 and sulfapyridine. In these equations, $\sigma^{*}$ are Taft sigma constants, and $\sigma_{\mathrm{p}}^{+}$and $\sigma_{\mathrm{o}, \mathrm{m}, \mathrm{p}}^{-}$are Hammett 215 sigma constants (Lee and von Gunten, 2012). Further details for the estimation of $k_{\mathrm{O}^{-}}$and $k_{\mathbf{O O H}^{-}}$ 216 values are described in Table S3.

\subsection{Ozone and ${ }^{\circ} \mathrm{OH}$ exposure, ${ }^{\circ} \mathrm{OH}$ yield, and ${ }^{\circ} \mathrm{OH}$ consumption rate constant in a hospital} wastewater effluent

Ozone exposures (i.e., $\int\left[\mathrm{O}_{3}\right] \mathrm{dt}$ ) were obtained from the area under the ozone decay curves or calculated indirectly from the elimination of carbamazepine (CMP) or bezafibrate (BZF) as ozone probe compounds (see results \& discussion sections for further details). ${ }^{\bullet} \mathrm{OH}$ exposures (i.e., $\left[\left[^{\circ} \mathrm{OH}\right]\right.$ ) were calculated from the elimination of $p \mathrm{CBA}$ (von Gunten, 2003a). The ${ }^{\circ} \mathrm{OH}$ yield during wastewater effluent ozonation was determined by measuring formaldehyde formation in the presence of excess tert-butanol (Nöthe et al., 2009; Lee et al., 2013). ${ }^{\circ} \mathrm{OH}$ reaction rate constant with wastewater matrix components were determined by a competition kinetic method using tert-butanol 227 (Nöthe et al., 2009; Lee et al., 2013). 


\subsection{Analytical methods}

230 A detailed description of the sample preparation and analysis for the 67 micropollutants can be 231 found elsewhere (Kovalova et al., 2012). Briefly, samples were filtered with a $0.7 \mu \mathrm{m} \mathrm{GF} / \mathrm{F}$ glass232 fiber filter (Whatman, Dassel, Germany) and further with a $0.2 \mu \mathrm{m}$ regenerated cellulose filter 233 (Sartorius AG, Göttingen, Germany), spiked with isotope labelled internal standards and analysed in 234 a single multi-compound method by online SPE-HPLC-MS/MS with a Triple Quadrupol mass 235 spectrometer (TSQ Quantum Ultra, Thermo Fisher Scientific). Limits of quantification are listed in 236 the Supporting Information (SI, Table S1). Concentrations of carbamazepine, bezafibrate, and $p$ CBA 237 in the $0.01-1 \mu \mathrm{M}$ range were determined with an Agilent $1100 \mathrm{HPLC} / \mathrm{UV}$ system (Lee and von 238 Gunten, 2010).

Ozone and hydrogen peroxide were determined by the indigo method (Bader and Hoigné, 1981) and the DPD/peroxidase method (Bader et al., 1988), respectively. Formaldehyde was determined by the pre-column derivatization into 2,4-dinitrophenyldydrazone and subsequent HPLC/UV analysis 242 (Lipari and Swarin, 1982). Dissolved organic carbon (DOC) was determined by a LC-OCD instrument (DOC-Labor, Karlsruhe, Germany) (Huber et al., 2011). Bromide was measured with ion chromatography (IC) with conductivity detection and bromate was measured with IC and UV detection after a post-column reaction (Salhi and von Gunten, 1999).

\section{Results and Discussions}

\subsection{Grouping micropollutants based on ozone and ${ }^{\circ} \mathrm{OH}$ reaction rate constants}

25 micropollutants were selected on the basis of their presence in the MBR permeate at 
252 of their elimination levels during ozonation (typically $0->90 \%$ ). These compounds were then 253 classified into five groups according to their $k_{\mathrm{O}^{-}}$and $k_{\bullet} \mathrm{OH}^{-v a l u e s}$ (Table 1$)$. The $k_{\mathrm{O}^{-}}$and $k_{\bullet} \mathrm{OH}^{-\mathrm{v} a l u e s}$ 254 for these compounds were taken from literature (see footnotes in Table 1) or predicted using the 255 QSAR and the group contribution method (Table S3). The criteria for grouping micropollutants 256 based on $k_{\mathrm{O}^{-}}$and $k_{\bullet \mathrm{OH}^{-}}$-values were proposed recently (Lee et al., 2013) and further adapted in this 257 study.

\section{8} $k_{03, \mathrm{pH} 7}$ and $k_{03, \mathrm{pH} 8.5} \geq 10^{4} \mathrm{M}^{-1} \mathrm{~s}^{-1}$ and group $\mathrm{Ib}=k_{\mathrm{O} 3, \mathrm{pH} 7}<10^{4} \mathrm{M}^{-1} \mathrm{~s}^{-1}$ and $k_{03, \mathrm{pH} 8.5} \geq 10^{4} \mathrm{M}^{-1} \mathrm{~s}^{-1}$.

263 These criteria were proposed to reflect the $\mathrm{pH}$ dependent $k_{03}$-values for amine-containing 264 compounds which typically increase from $<10^{4} \mathrm{M}^{-1} \mathrm{~s}^{-1}$ at $\mathrm{pH} 7$ to $>10^{4} \mathrm{M}^{-1} \mathrm{~s}^{-1}$ at $\mathrm{pH} 8.5$ (a factor of 265 10 increase of the $k_{\mathrm{O} 3}$-value per unit $\mathrm{pH}$ increase). Therefore, the elimination efficiency of group Ib 266 can differ considerably within the $\mathrm{pH}$ range $7-8.5$. Group Ia includes compounds with phenols, 267 anilines (aromatic amine-N), olefins, thioethers, tertiary/secondary aliphatic amines with $\mathrm{pK}_{\mathrm{a}}$ values 268 of $<9$, and combinations thereof. Group Ib includes compounds with tertiary or secondary aliphatic 269 amines with $\mathrm{pK}_{\mathrm{a}}$ values of $>9$. Group Ia compounds include carbamazepine (olefin), clarithromycin 270 (tertiary amine), diclofenac (aromatic amine-N), furosemide (aromatic amine-N), lidocaine (tertiary 271 amine and activated benzene), mefenamic acid (aromatic amine- $\mathrm{N}$ or activated benzene), ranitidine 272 (thioether and tertiary amine), sotalol (activated benzene and secondary amine), sulfamethoxazole 273 (aromatic amine-N), and sulfapyridine (aromatic amine-N). The moieties in the parenthesis indicate 274 the expected main reaction sites (for the chemical structures, see Table S2). Phenolic compounds 
usually belong to group Ia (Lee et al., 2013) but in this study no phenolic micropollutants was quantified above $0.1 \mu \mathrm{g} / \mathrm{L}$ in the tested wastewater effluent. Group $\mathrm{Ib}$ includes atenolol-acid 277 (secondary amine), 4-methylbenzotriazole (activated benzene), metoprolol (secondary amine), 278 tramadol (tertiary amine), and venlafaxine (tertiary amine) (Table 1).

Group II compounds have intermediate reactivities with ozone $\left(50 \leq k_{\mathrm{O} 3, \mathrm{pH} 7}\right.$ and $k_{\mathrm{O} 3, \mathrm{pH} 8.5}<10^{4}$ 280 $\mathrm{M}^{-1} \mathrm{~s}^{-1}$ ) and include $\mathrm{N}(4)$-acetyl-sulfamethoxazole, benzotriazole, and bezafibrate with activated 281 benzenes and gabapentin with a primary amine as the ozone-reactive sites, respectively (Table 1).

282 The $k_{03}$-values of benzotriazole and gabapentin increase by a factor of 10 and 30 , respectively, with 283 an increase of $\mathrm{pH}$ from 7 to 8.5 due to the presence of a dissociable triazole and primary amine 284 moiety, respectively. Group III compounds have low reactivities with ozone $\left(k_{\mathrm{O} 3, \mathrm{pH} 7}\right.$ and $k_{\mathrm{O} 3, \mathrm{pH} 8.5}<$ 285 $\left.50 \mathrm{M}^{-1} \mathrm{~s}^{-1}\right)$ while appreciable reactivities with ${ }^{\circ} \mathrm{OH}\left(k_{\bullet \mathrm{OH}} \geq 5 \times 10^{9} \mathrm{M}^{-1} \mathrm{~s}^{-1}\right)$. Oxazepam, primidone, 286 and valsartan were classified into group III. These compounds contain benzene with mono- or di287 substitution(s) (e.g., alkyl or halogen) in which ${ }^{\circ} \mathrm{OH}$ shows still high reactivity due to its rapid 288 benzene ring-addition mechanism (Minakata et al., 2009). In addition to weakly-activated benzenes, 289 aliphatic hydrocarbons with electron-donating alkyl substituents and $>5 \mathrm{C}$ atoms can show high 290 amide-moieties all of which show negligible reactivity to ozone and low reactivity to ${ }^{\circ} \mathrm{OH}$. Similarly, 294 levetiracetam is composed of short hydrocarbon chains with amide-moieties (Table S2). 
Duplicate ozonation experiments were performed for each treatment condition and each treated sample was analyzed twice. Figures $1-3$ show the obtained percentage (\%) elimination data for the

selected 25 micropollutants (Table 1). Error bars represent standard deviations of the measurements at each treatment condition. The standard deviations were usually below $5 \%$ and increased up to $9 \%$ for only a few cases, indicating that the results were quite reproducible. Figure S3 or Table S4 shows the average $\%$ elimination data for each group of micropollutants.

Figure 1 shows the $\%$ elimination of the group Ia (carbamazepine, clarithromycin, diclofenac,

304 furosemide, lidocaine, mefenamic acid, ranitidine, sotalol, sulfamethoxazole, and sulfapyridine) and 305 group $\mathrm{Ib}$ (atenolol acid, 4-methylbenzotriazole, metoprolol, tramadol, and venlafaxine) micropollutants as a function of the specific ozone doses $\left(\mathrm{gO}_{3} / \mathrm{gDOC}=0.25,0.5,1.0\right.$, and 1.5$)$ at $\mathrm{pH}$ 7.0 and 8.5. The elimination of group Ia compounds was efficient: at $\mathrm{gO}_{3} / \mathrm{gDOC} \geq 0.5$, the elimination level approached the method quantification limit (>92-100\%) at both $\mathrm{pH}$ conditions. Even at $\mathrm{gO}_{3} / \mathrm{gDOC}=0.25$, the average elimination level was $80 \%(65-92 \%)$ which is still considerable (Figure S3). This elimination level is comparable to that observed in municipal wastewater effluents $(=91 \%)$ at the same specific ozone dose (i.e., $\mathrm{gO}_{3} / \mathrm{gDOC}=0.25$ ) with a negligible of ozone demand exerted by nitrite (Lee et al., 2013). The high elimination efficiency for 313 group Ia compounds can be attributed to their high apparent $k_{03}$-values $\left(k_{03, \mathrm{pH} 7}\right.$ and $k_{03, \mathrm{pH} 8.5}>10^{4}$ $314 \mathrm{M}^{-1} \mathrm{~s}^{-1}$, Table 1). Direct ozone reactions mainly contributed to the elimination of these compounds, 315 i.e., $74 \%$ at $\mathrm{pH} 7.0$ and $814 \%$ at $\mathrm{pH} 8.5$ and the remaining $\leq 26 \%$ was due to the reaction with ${ }^{\circ} \mathrm{OH}$ 316 (Figure S4). The elimination level at $\mathrm{gO}_{3} / \mathrm{gDOC}=0.25$ decreased slightly $(<6 \%)$ with an increase of $317 \mathrm{pH}$ from 7.0 to 8.5 for carbamazepine, diclofenac, furosemide, mefenamic acid, ranitidine, 318 sulfamethoxazole, and sulfapyridine. These compounds except sulfapyridine show near constant $319 k_{\mathrm{O} 3 \mathrm{pH} 7^{-}}$and $k_{\mathrm{O}, \mathrm{pH} 8.5^{-}}$-values as the corresponding ozone-reactive moieties do not change their 
speciation with variations in $\mathrm{pH}$ (Table 1). The reduction in elimination efficiency can be explained

321 by the slightly reduced ozone exposure in the tested wastewater effluent at the higher $\mathrm{pH}$ caused by a

322 more rapid ozone decay (Hoigné, 1998). In contrast, the elimination level slightly increased for

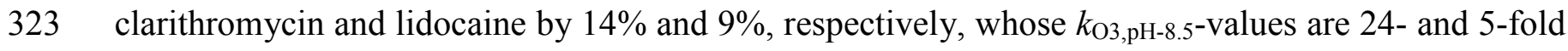

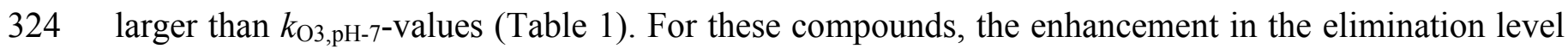
325 by the larger $k_{\mathrm{O} 3}$-value outcompeted the smaller ozone exposure at the higher $\mathrm{pH}$.

326 The elimination efficiency of group Ib compounds was lower than for group Ia, especially for $\mathrm{pH}$

327 7, which is consistent with their lower $k_{03}$-values (Table 1). The average elimination levels of group $328 \mathrm{Ib}$ compounds at $\mathrm{pH} 7$ were $36 \%$ and $77 \%$ at $\mathrm{gO}_{3} / \mathrm{gDOC}$ of 0.25 and 0.5 , respectively, and $>98 \%$ at 329 $\mathrm{gO}_{3} / \mathrm{gDOC} \geq 1.0$. For $\mathrm{pH} 8.5$, the average elimination levels were $53 \%$ and $96 \%$ at $\mathrm{gO}_{3} / \mathrm{gDOC}$ of 0.25 and 0.5 , respectively, which were about $20 \%$ larger compared to those for $\mathrm{pH} 7$. Near complete elimination (>98\%) was achieved at $\mathrm{gO}_{3} / \mathrm{gDOC} \geq 0.5$ with an elimination pattern similar to the group Ia compounds (Figure S3). This result is consistent with the larger (22 \pm 6 -fold) $k_{03, \mathrm{pH} 8.5}$-values than $k_{\mathrm{O} 3, \mathrm{pH} 7}-\mathrm{values}$ for the group Ib compounds. The contribution of the direct ozone reaction to the overall elimination for the group Ib compounds was $26 \%$ and $67 \%$ at $\mathrm{pH} 7.0$ and 8.5 , respectively, which was lower than for group Ia (Figure S4). For $\mathrm{pH} 7,{ }^{\circ} \mathrm{OH}$ contributed more than ozone to the elimination of group $\mathrm{Ib}$ compounds due to relatively low $k_{\mathrm{O} 3 \mathrm{pH}}$-values $\left(<10^{4} \mathrm{M}^{-1} \mathrm{~s}^{-1}\right)$.

The \% eliminations of group II (N(4)-acetyl-sulfamethoxazole, benzotriazole, bezafibrate, and gabapentin), group III (oxazepam, primidone, and valsartan), and group IV compounds (fluconazole, iopromide, and levetiracetam) are shown in Figure 2. The elimination of $p \mathrm{CBA}$ as an ${ }^{\circ} \mathrm{OH}$-probe

340 compound is also shown in Figure 2 for comparison. The elimination efficiency of the group II 341 compounds is lower than that of groups $\mathrm{Ia} \& \mathrm{Ib}$, which is consistent with their lower $k_{03}$-values 342 (Table 1). The average elimination levels of the group II compounds at $\mathrm{pH} 7$ were $28 \%, 55 \%, 92 \%$, 
343 and $>95 \%$ at $\mathrm{gO}_{3} / \mathrm{gDOC}$ of $0.25 .0 .5,1.0$, and 1.5 , respectively. At $\mathrm{pH} 8.5$, the average elimination

344 levels were slightly lower: $19 \%, 46 \%, 88 \%$, and $>95 \%$ at the same specific ozone doses, respectively

345 (Figure S3). For the group II compounds, reactions with ${ }^{\bullet} \mathrm{OH}$ are estimated to be mainly responsible 346 for their elimination and their contribution is $89 \%$ and $92 \%$ at $\mathrm{pH} 7$ and 8.5 , respectively (Figure S4).

347 Therefore, the lower elimination level with the $\mathrm{pH}$ increase for the group II compounds is mainly 348 attributed to a reduced diminished ${ }^{\bullet} \mathrm{OH}$ exposure. It will be shown later that the ${ }^{\bullet} \mathrm{OH}$ consumption 349 rate increases by a factor of 2 with an increase of $\mathrm{pH}$ from 7.0 to 8.5 , which is consistent with a 350 reduced $^{\bullet} \mathrm{OH}$ exposure.

351 The average elimination levels of group III compounds at $\mathrm{pH} 7$ were $29 \%, 55 \%, 91 \%$, and $>96 \%$ 352 at $\mathrm{gO}_{3} / \mathrm{gDOC}$ of $0.25,0.5,1.0$, and 1.5 , respectively. At $\mathrm{pH} 8.5$, the average elimination levels were 353 slightly lower and were $21 \%, 45 \%, 79 \%$, and $>92 \%$ at the same specific ozone doses, respectively 354 (Figure S3). This similar elimination efficiency for the group II and III compounds can be explained 355 by the fact that ${ }^{\circ} \mathrm{OH}$ is mainly responsible for their elimination (Figure S4) and the $k_{\bullet} \mathrm{OH}^{-\mathrm{v}}$ alues for 356 these compounds are quite similar $\left(6.8 \times 10^{9}<k_{\bullet \mathrm{OH}}<10^{10} \mathrm{M}^{-1} \mathrm{~s}^{-1}\right.$, Table 1$)$. The lower elimination 357 levels at the higher $\mathrm{pH}$ observed for oxazepam and valsartan can again be explained by a lower ${ }^{\bullet} \mathrm{OH}$ 358 exposure (see below). The elimination levels of $p$ CBA were slightly lower than that of group II and 359 III compounds but the elimination behaviour was quite similar, which is consistent with the 360 reactivity of $p$ CBA with ozone and ${ }^{\bullet} \mathrm{OH}\left(k_{\mathrm{O} 3}<1 \mathrm{M}^{-1} \mathrm{~s}^{-1}\right.$ and $k_{\bullet \mathrm{OH}}=5 \times 10^{9} \mathrm{M}^{-1} \mathrm{~s}^{-1}$, von Gunten, $3612003 a)$.

362 The elimination levels of group IV compounds (fluconazole, iopromide, and levetiracetam) were 363 lower than for the other groups and were $17 \%, 31 \%, 64 \%$, and $>83 \%$ for $\mathrm{pH} 7$ and $13 \%, 31 \%, 50 \%$, 364 and $>69 \%$ for $\mathrm{pH} 8.5$ at $\mathrm{gO}_{3} / \mathrm{gDOC}$ of $0.25,0.5,1.0$, and 1.5 , respectively (Figure $\mathrm{S} 3$ ). The lower 365 elimination of group IV is attributed to the lower $k_{\bullet} \mathrm{OH}^{-\mathrm{v} a l u e s}$ for these compounds, $k_{\bullet} \mathrm{OH}=$ 
$366(3.3-4.4) \times 10^{9} \mathrm{M}^{-1} \mathrm{~s}^{-1}$ (Table 1). The reaction of ${ }^{\bullet} \mathrm{OH}$ was estimated to be $100 \%$ responsible for the

367 elimination of fluconazole and levetiracetam. For iopromide, however, the reaction of ${ }^{\bullet} \mathrm{OH}$ explained 368 only $84 \%$ and $53 \%$ of its elimination at $\mathrm{pH} 7$ and 8.5 , respectively (Figure S4). As iopromide has

369 negligible reactivity to ozone $\left(k_{\mathrm{O} 3}<0.8 \mathrm{M}^{-1} \mathrm{~s}^{-1}\right.$, Table 1$)$, the reaction of ozone is not expected to 370 contribute to the observed additional elimination of iopromide. Similar underestimation for the 371 elimination of iopromide by ${ }^{\bullet} \mathrm{OH}$ reaction was also observed previously during ozonation of river 372 waters (Huber et al., 2003).

373

374

\subsection{Effect of hydrogen peroxide $\left(\mathrm{H}_{2} \mathrm{O}_{2}\right)$}

375

$\mathrm{H}_{2} \mathrm{O}_{2}$ can be added to an ozonation process to accelerate ozone decay and thus the ${ }^{\bullet} \mathrm{OH}$ formation rate (von Gunten, 2003a). However, it was previously shown that $\mathrm{H}_{2} \mathrm{O}_{2}$ addition during wastewater ozonation had a marginal influence on the micropollutant elimination efficiency (Lee et al., 2013; Kovalova et al. 2013). This is caused by a rapid consumption of ozone by EfOM (within a few minutes) for relatively low specific ozone doses $\left(\mathrm{gO}_{3} / \mathrm{gDOC}<0.5\right)$. This reaction outcompetes the 380 relatively slow reaction of ozone with $\mathrm{H}_{2} \mathrm{O}_{2}$. Therefore, there is a limited effect on the elimination 381 efficiency of the ozone-reactive micropollutants (i.e., group I), which is already high $(>80 \%$ 382 elimination). For ozone-resistant micropollutants (i.e., groups III and IV), the elimination efficiency 383 increased only slightly $(<10 \%)$ by addition of $\mathrm{H}_{2} \mathrm{O}_{2}$ during ozonation of wastewater effluents at $\mathrm{pH}$ $384 \sim 7$ (Lee et al., 2013). This can be attributed to the slightly higher yield of ${ }^{\bullet} \mathrm{OH}$ in the $\mathrm{O}_{3} / \mathrm{H}_{2} \mathrm{O}_{2}$ 385 process compared to conventional ozonation. For drinking waters with lower DOC and high 386 carbonate in which ozone decay is slow, nevertheless, it was shown that $\mathrm{H}_{2} \mathrm{O}_{2}$ had a larger effect on 387 the elimination efficiency of ozone-resistant micropollutants (Acero and von Gunten, 2001). 
Figure 3 shows the \% elimination of the groups II, III, and IV compounds during ozonation of wastewater effluent at $\mathrm{pH} 7.0$ and 8.5 with $\mathrm{gO}_{3} / \mathrm{gDOC}=1.0$ and molar ratios of $\mathrm{H}_{2} \mathrm{O}_{2} / \mathrm{O}_{3}$ of $0,0.25$, and 0.5 . For $\mathrm{pH} 7$, the elimination level for all compounds changed little or slightly increased $(<8 \%)$ upon $\mathrm{H}_{2} \mathrm{O}_{2}$ addition, which is consistent with the results from a previous study (Lee e al., 2013). For 392 $\mathrm{pH}$ 8.5, however, the $\mathrm{H}_{2} \mathrm{O}_{2}$ addition $\left(\mathrm{H}_{2} \mathrm{O}_{2} / \mathrm{O}_{3}(\mathrm{~mol} / \mathrm{mol})=0.5\right)$ resulted in reductions of the elimination levels by $16-31 \%$ for the group II compounds. This might be explained by the 394 decreased ozone exposure upon the $\mathrm{H}_{2} \mathrm{O}_{2}$ addition at $\mathrm{pH} 8.5$ and the still important contribution of ozone to the elimination of group II compounds. The reaction rate of ozone with $\mathrm{H}_{2} \mathrm{O}_{2}$ increases by a 396 factor of 32 by increasing the $\mathrm{pH}$ from 7 to 8.5 (Staehelin and Hoigné, 1982), which may increase the ozone decay rate and therefore reduce the ozone exposure significantly at $\mathrm{pH} 8.5$. For the group 398 III and IV compounds, the elimination level changed marginally ( $<5 \%$ decreases) except for oxazepam, primidone, and iopromide. The elimination level of $p$ CBA increased $7 \%$ upon $\mathrm{H}_{2} \mathrm{O}_{2}$ addition. This is consistent with previous observations that the ${ }^{\bullet} \mathrm{OH}$ scavenging rate or ${ }^{\bullet} \mathrm{OH}$ exposure is not significantly affected by $\mathrm{H}_{2} \mathrm{O}_{2}$ addition and ${ }^{\circ} \mathrm{OH}$ is mainly responsible for the elimination of these compounds (Acero and von Gunten, 2001). However, the elimination level for oxazepam, 403 primidone, and iopromide decreased by $17 \%, 13 \%$, and $12 \%$, respectively. Analytical uncertainty might be responsible for this unexpected behavior, but the reason is currently not entirely clear. Overall, it is concluded that $\mathrm{H}_{2} \mathrm{O}_{2}$ addition has a marginally positive ( $\mathrm{pH}$ 7) or even a negative effect 406 $(\mathrm{pH} 8.5)$ on the micropollutant elimination efficiency during ozonation of the selected hospital wastewater effluent.

\section{4. ${ }^{\bullet} \mathrm{OH}$ and ozone exposures}


Figure 4 shows the ${ }^{\circ} \mathrm{OH}$ exposures determined in the tested wastewater effluents at $\mathrm{pH} 7.0$ and

4118.5 as a function of the specific ozone dose. The ${ }^{\bullet} \mathrm{OH}$ exposure increased linearly with increasing

412 ozone doses and the data could be approximated by using two linear regressions with the specific

413 ozone dose ranges of $0 \leq \mathrm{gO}_{3} / \mathrm{gDOC}<\sim 0.6$ (phase $\mathrm{I}$ ) and $0.6<\mathrm{gO}_{3} / \mathrm{gDOC} \leq 1.7$ (phase II). The

414 slope of the linear lines in Figure 4 represents the increase of ${ }^{\bullet} \mathrm{OH}$ exposure per specific ozone dose

415 (i.e., $\Delta\left[{ }^{\bullet} \mathrm{OH}\right.$ exposure $] /\left(\mathrm{gO}_{3} / \mathrm{gDOC}\right)$ ) and was $2.4 \times 10^{-10} \mathrm{M} \mathrm{s}$ (phase I) and $4.5 \times 10^{-10} \mathrm{M} \mathrm{s}$ (phase II)

416 for $\mathrm{pH} 7$ and $1.9 \times 10^{-10} \mathrm{M} \mathrm{s}$ (phase I) and $3.2 \times 10^{-10} \mathrm{M} \mathrm{s}$ (phase II) for $\mathrm{pH} 8.5$. The lower slopes in

417 phase I compared to phase II could be due to the ozone consumption by EfOM moieties with less

$418{ }^{\circ} \mathrm{OH}$ formation (e.g., olefins or tertiary amines). Alternatively, a decreasing ${ }^{\circ} \mathrm{OH}$ scavenging rate by

419 EfOM with increasing ozone dose due to EfOM oxidation might explain the higher slopes in the

420 phase II compared to the phase I. Nevertheless, it should be noted that this is just an empirical

421 interpretation of the two-phasic behavior of the ${ }^{\circ} \mathrm{OH}$ exposure. The observed slopes in the phase II

422 are within the ranges reported previously for municipal wastewater effluents $\left(3.0 \times 10^{-10}-5.3 \times 10^{-10}\right.$

423 M s, Lee et al., 2013).

424 Ozone exposures determined at various specific ozone doses are shown in Figure 5. The ozone 425 exposures for $\mathrm{gO}_{3} / \mathrm{gDOC}=1$ were measured directly from the area under the ozone decay curves 426 (Figure $\mathrm{S} 5$ ). The ozone exposures for $\mathrm{gO}_{3} / \mathrm{gDOC}$ of 0 to 1 were determined indirectly on the basis of 427 the elimination of carbamazepine (CMP) and bezafibrate (BZF) in the following two different 428 specific ozone dose range, i.e., $\mathrm{gO}_{3} / \mathrm{gDOC}=0.05-0.3$ using $\mathrm{CMP}$ and $0.3-0.7$ using $\mathrm{BZF}$, 429 respectively. Eq 2 can be derived from a rearrangement of the eq 1 and used to calculate the ozone 430 exposure:

$$
\int\left[\mathrm{O}_{3}\right] \mathrm{dt}=-\frac{\left(\ln \left(\frac{[\mathrm{P}]}{\mathrm{P}] 0}\right)+k_{\cdot \mathrm{OH}-\mathrm{P}} \int \cdot \mathrm{OHdt}\right)}{k_{03-\mathrm{P}}}
$$


432 in which $\ln \left(\frac{[P]}{[P]_{0}}\right)$ is the logarithmic elimination of the ozone-probe compound $(\mathrm{P}=\mathrm{CMP}$ or $\mathrm{BZF})$,

$433 \int\left[{ }^{\bullet} \mathrm{OH}\right] \mathrm{dt}$ is the ${ }^{\bullet} \mathrm{OH}$ exposure and can be calculated as $-\frac{\ln \left(\frac{[p \mathrm{CBA}]}{[p \mathrm{CBA}] 0}\right)}{k_{\bullet \mathrm{OH}-p \mathrm{CBA}}}$ with $k_{\bullet} \mathrm{OH}-p \mathrm{CBA}=5 \times 10^{9} \mathrm{M}^{-1} \mathrm{~s}^{-1}$, 434 and $k_{\mathrm{O} 3-\mathrm{CMP}}=3 \times 10^{5} \mathrm{M}^{-1} \mathrm{~s}^{-1}$ or $k_{\mathrm{O} 3-\mathrm{BZF}}=5.9 \times 10^{2} \mathrm{M}^{-1} \mathrm{~s}^{-1}$ (Huber et al., 2003). CMP and BZF were 435 selected in this study based on their reliable, $\mathrm{pH}$-independent, and representative $k_{\mathrm{O} 3 \text {-values }}$ (high $k_{\mathrm{O} 3}$ 436 for $\mathrm{CMP}$ and intermediate $k_{\mathrm{O} 3}$ for $\mathrm{BZF}$ ), and their frequent occurrence in municipal wastewater 437 effluents (Oulton et al., 2010). This indirect method for ozone exposure determination can be applied 438 especially for low ozone doses (e.g., $\left.\mathrm{gO}_{3} / \mathrm{DOC}<0.5\right)$ in which ozone decay is usually too fast to be 439 measured using conventional kinetic methods. Nevertheless, it should be noted that this method 440 gives a rough estimate for ozone exposure due to cumulative uncertainty in $\ln \left(\frac{[P]}{[P]_{0}}\right), \int\left[{ }^{\circ} \mathrm{OH}\right] \mathrm{dt}$, and $441 k_{\mathrm{O} 3-\mathrm{P}}$ values. The indirect method can be further calibrated against real ozone exposure measurements 442 using rapid kinetic systems such as quench-flow or stopped-flow (Buffle et al., 2006a; Buffle et al., 443 2006b; Nöthe et al., 2009; Lee et al., 2013).

444 Figure 5 shows the logarithm of the ozone exposures (linear scale in the inset) determined at 445 various specific ozone doses for $\mathrm{pHs} 7.0$ and 8.5. The ozone exposure increased exponentially with 446 increasing ozone dose with almost four orders of magnitude variation. For $\mathrm{pH} 7$, the ozone exposures 447 were $0.6 \times 10^{-5}, 0.5 \times 10^{-3}$, and $0.8 \times 10^{-2} \mathrm{M} \mathrm{s}$ for $\mathrm{gO}_{3} / \mathrm{gDOC}$ of $0.25,0.5$, and 1.0 , respectively. For $\mathrm{pH}$ 4488.5 , the ozone exposures were lower than at $\mathrm{pH} 7$ and were $0.4 \times 10^{-5}, 0.3 \times 10^{-3}$, and $0.2 \times 10^{-2} \mathrm{M} \mathrm{s}$, 449 respectively, for the same specific ozone doses. The determined ozone exposures in the tested 450 wastewaters at $\mathrm{pH} 7$ are comparable or within literature values measured for municipal wastewater 451 effluents at $\mathrm{pH} 7.2( \pm 0.2): 1.5 \times 10^{-5},(0.2-2.8) \times 10^{-3}$, and $(0.4-1.3) \times 10^{-2} \mathrm{M} \mathrm{s}$ for $\mathrm{gO}_{3} / \mathrm{gDOC}$ of 0.25 , 4520.5 , and 1.0, respectively, which were determined directly from the areas under the ozone decay 453 curves (Lee et al., 2013). 


\subsection{Prediction of micropollutant elimination}

The determined ozone and ${ }^{\bullet} \mathrm{OH}$ exposures (Figures 4 and 5) were used to predict the elimination

457 levels of 25 micropollutants (Table 1) as a function of specific ozone dose by eq 1. Figure 6 shows 458 that for both $\mathrm{pH}$ conditions, the elimination prediction is reasonable: for $\mathrm{pH} 7, \mathrm{r}^{2}=0.87$, and the 459 standard errors of estimate $\left(\mathrm{S}_{\mathrm{y}, \mathrm{x}}\right)=9.6$; for $\mathrm{pH} 8.5, \mathrm{r}^{2}=0.84$, and $\mathrm{S}_{\mathrm{y}, \mathrm{x}}=11.6$. This result clearly 460 shows the usefulness of the chemical kinetic approach based on the measurements of the ozone and $461{ }^{\circ} \mathrm{OH}$ exposure and the $k_{\mathrm{O} 3}$ and $k_{\bullet} \mathrm{OH}^{-}$values in predicting elimination levels of various micropollutants. 462 In addition, the indirect method for estimating ozone exposures using CMP or BZF as the ozone463 probe compound was found to be applicable. Figures S6 - S9 show the measured and predicted \% 464 elimination of each group of micropollutants (i.e., group I - IV). The predictions were less accurate 465 (lower $\mathrm{r}^{2}$ and $\mathrm{S}_{\mathrm{y}, \mathrm{x}}$ values) for ozone-reactive (e.g., group I) than for ozone-resistant compounds (e.g., 466 group III), which indicates the relative larger uncertainty of the ozone exposures than the $\mathrm{OH}$ 467 exposures. The less accurate prediction for $\mathrm{pH} 8.5$ than $\mathrm{pH} 7.0$ could be attributed to the different elimination behaviors of the group II, III, and IV compounds compared to that of $p \mathrm{CBA}$ for $\mathrm{pH} 8.5$, which was mentioned earlier.

\section{6. ${ }^{\circ} \mathrm{OH}$ yield and ${ }^{\circ} \mathrm{OH}$ consumption kinetics}

472

As ${ }^{\bullet} \mathrm{OH}$ plays an important role for the elimination of ozone-refractory compounds, (a) the ${ }^{\bullet} \mathrm{OH}$ formation, and (b) the ${ }^{\bullet} \mathrm{OH}$ yields (moles of ${ }^{\bullet} \mathrm{OH}$ produced per mole of ozone consumed) as a 474 function of specific ozone dose were investigated in the tested hospital wastewater effluent (Figure 7). The ${ }^{\bullet} \mathrm{OH}$ yield generally increased with increasing ozone dose, which could be approximated by a 
477 yield $(\%)=6.7( \pm 2.7) \times\left(\mathrm{gO}_{3} / \mathrm{gDOC}\right)+20.7( \pm 3.0), \mathrm{r}^{2}=0.71$ for $\mathrm{pH} 7$ and $11.2( \pm 3.2) \times\left(\mathrm{gO}_{3} / \mathrm{gDOC}\right)+$ $47822.0( \pm 3.6), \mathrm{r}^{2}=0.83$ for $\mathrm{pH}$ 8.5. The determined ${ }^{\circ} \mathrm{OH}$ yields for $\mathrm{pH} 7(=20-34 \%)$ are comparable 479 to the values reported previously for municipal wastewater effluents while the ${ }^{\bullet} \mathrm{OH}$ yields for $\mathrm{pH} 8.5$ $480(=19-41 \%)$ were on average $6 \%$ higher compared to $\mathrm{pH} 7$, which is opposite to the trend observed 481 for the ${ }^{\bullet} \mathrm{OH}$ exposure. This contradiction can be explained by a significantly higher ${ }^{\circ} \mathrm{OH}$ 482 consumption rate with increasing $\mathrm{pH}$, resulting in a lower ${ }^{\circ} \mathrm{OH}$ exposure.

483 The ${ }^{\bullet} \mathrm{OH}$ consumption rate was determined by a competition kinetics method using tert-butanol 484 as a competitor for $\mathrm{gO}_{3} / \mathrm{gDOC}=1$. As shown in Figure 8, the ${ }^{\bullet} \mathrm{OH}$ consumption rate was $1.5 \times 10^{5} \mathrm{~s}^{-1}$ 485 at $\mathrm{pH} 7$ and $2.9 \times 10^{5} \mathrm{~s}^{-1}$ at $\mathrm{pH} 8.5$. Using the information for the concentration of carbonate species in 486 the tested wastewater effluent $\left(\left[\mathrm{HCO}_{3}{ }^{-} / \mathrm{CO}_{3}{ }^{2-}\right]=7.7 \mathrm{mM}\right)$ and the ${ }^{\circ} \mathrm{OH}$ reaction rate constant with 487 carbonate species $\left(\mathrm{k}_{\bullet \mathrm{OH} / \mathrm{HCO}{ }_{-}}=8.5 \times 10^{6} \mathrm{M}^{-1} \mathrm{~s}^{-1}\right.$ and $\mathrm{k}_{\bullet} \mathrm{OH} / \mathrm{CO} 2_{-}=3.9 \times 10^{8} \mathrm{M}^{-1} \mathrm{~s}^{-1}$, Buxton et al., $488 \mathrm{1}^{1988)}$, the ${ }^{\bullet} \mathrm{OH}$ consumption rates by carbonate species were calculated to be $5.0 \times 10^{4}$ and $9.9 \times 10^{4}$ $489 \mathrm{~s}^{-1}$ for $\mathrm{pH} 7.0$ and 8.5 , respectively, which are about $35 \%$ of the overall ${ }^{\bullet} \mathrm{OH}$ consumption rate. This 490 indicates a significant formation of $\mathrm{CO}_{3}{ }^{--}$in the tested wastewater effluent. The increase in the $\mathrm{CO}_{3}{ }^{2-}$ 491 fraction of the total carbonate with increasing $\mathrm{pH}$ is responsible for the two-fold increase of the ${ }^{\bullet} \mathrm{OH}$ 492 consumption rate by carbonate species. The remaining ${ }^{\circ} \mathrm{OH}$ consumption rate is attributed to the 493 contribution by EfOM allowing determination of the second-order rate constants for the reaction of $494{ }^{\circ} \mathrm{OH}$ with $\mathrm{EfOM}\left(k_{\bullet \mathrm{OH} / \mathrm{EfOM}}\right)$ as $k_{\bullet \mathrm{OH} / \mathrm{EfOM}}=2.0 \times 10^{4}$ and $4.1 \times 10^{4} \mathrm{M}^{-1} \mathrm{~s}^{-1}$ at $\mathrm{pH} 7$ and 8.5 , respectively. 495 The $\sim$ two-fold greater $k_{\bullet}$ OH-EfOM-value at $\mathrm{pH} 8.5$ than at $\mathrm{pH} 7$ might be attributed to deprotonation of 496 phenol- or amine-moieties in EfOM resulting in higher ${ }^{\bullet} \mathrm{OH}$ reaction rate constants (Buxton et al., 497 1988). Overall, the $\sim$ two-fold increase of the overall ${ }^{\circ} \mathrm{OH}$ consumption rate for $\mathrm{pH} 8.5$ compared to $498 \mathrm{pH} 7$ is consistent with the diminished ${ }^{\bullet} \mathrm{OH}$ exposure. 
The average $k_{\bullet \mathrm{OH} / \mathrm{EfOM}}$-value during ozonation of municipal wastewater effluents at $\mathrm{pH} 7.2( \pm 0.2)$

was reported to be $(2.1 \pm 0.6) \times 10^{4}\left(\mathrm{mgC}_{\mathrm{L}}\right)^{-1} \mathrm{~s}^{-1}$ (Lee et al., 2013) or $\sim 2.5 \times 10^{4}(\mathrm{mgC} / \mathrm{L})^{-1} \mathrm{~s}^{-1}$ (Lee

and von Gunten, 2010; von Sonntag and von Gunten, 2012), which is similar to the $k_{\bullet \cdot O H / E f O M}$-value

determined in this study for $\mathrm{pH} 7$. However, it was reported previously that $k_{\bullet}$ oH-Efom-values

\section{3}

increased with decreasing average MW of the EfOM (Dong et al., 2010). Our data support previous

observations that $k_{\bullet} \mathrm{OH} / \mathrm{EfOM}^{-}$-values do not depend strongly on size characteristics of EfOM (Lee et al.,

2013). The EfOM in the tested wastewater effluent is taken from the MBR permeate that is mainly

composed of molecular weight $(\mathrm{MW})$ fractions of $<1 \mathrm{kDa}$ due to the removal of larger biopolymer

fractions $(\mathrm{MW}>10 \mathrm{kDa})$ by ultrafiltration (Figure $\mathrm{S} 1)$.

\subsection{Prediction of the elimination for other micropollutants detected in hospital wastewater}

\section{effluent}

Among the 67 target analytes monitored during the pilot-scale MBR operation for the hospital wastewater treatment, 56 micropollutants were detected in the MBR permeates (Kovalova et al., 2012 \& 2013). For 25 micropollutants (Table 1), the elimination efficiency could be well predicted

514 using the kinetic information (i.e., ozone and ${ }^{\bullet} \mathrm{OH}$ rate constants and exposures). The same approach can be used to predict the elimination efficiency of the remaining 31 micropollutants based on $k_{\mathrm{O} 3}$ and $k_{\bullet \mathrm{OH}}$. For this, unknown $k_{\mathrm{O}^{-}}$and $k_{\bullet} \mathrm{OH}^{-}$values were estimated for 22 micropollutants using a

517 QSAR and the group contribution methods, respectively (Tables S2 \& S3). For the other 9 518 micropollutants, the $k_{\mathrm{O}^{-}}$and $k_{\bullet \mathrm{OH}^{-}}$-values were taken from literature (Table $\mathrm{S} 2$ ). As a next step, these 51931 micropollutants were classified into the five groups based on their $k_{\mathrm{O}^{-}}$and $k_{\bullet} \mathrm{OH}^{-\mathrm{v} a l u e s}$ (Table S2). 520 Based on this assessment, 38 among the 56 micropollutants belong to groups Ia \& Ib, indicating 521 two-thirds of the micropollutants found in the hospital wastewater effluent can be efficiently 
522 eliminated (e.g., $>80 \%$ at $\mathrm{gO}_{3} / \mathrm{gDOC}=0.5$ ). It is also noteworthy that all iodinated contrast media

523 belong to group IV (iomeprol, iopamidol, iopromide, and ioxitalamic) or group V (diatrizoate)

524 compounds (Table S2), which require high specific ozone doses for sufficient elimination (e.g., $70 \%$

525 elimination levels for $\mathrm{gO}_{3} / \mathrm{gDOC}=1.0$ ). A previous study found that over $80 \%$ of the micropollutant

526 load in effluents of a MBR-treated hospital wastewater was due to iodinated contrast media

527 (Kovalova et al., 2012).

528

529

3.8. Bromate formation

530

Ozonation of bromide-containing waters can form bromate, a probable human carcinogen with a

531 drinking water standard of $10 \mu \mathrm{g} / \mathrm{L}$ (von Gunten, 2003b). Information is currently limited for

532 bromate formation levels during ozonation of municipal wastewater effluents. Figure S10 (or Table

533 S5) shows the bromate formation at (a) $\mathrm{pH} 7$ and (b) $\mathrm{pH} 8.5$ as a function of the specific ozone dose

534 after treatment of the selected hospital wastewater effluent with ozone alone and ozone/hydrogen

535 peroxide. Under both $\mathrm{pH}$ conditions, bromate formation was less than $10 \mu \mathrm{g} / \mathrm{L}$ at $\mathrm{gO}_{3} / \mathrm{gDOC}^{\circ} \leq 1.0$,

536 and smaller at $\mathrm{pH} 8.5$ than $\mathrm{pH} 7.0$ which is consistent with lower exposures for ozone and ${ }^{\circ} \mathrm{OH}$. The

537 low bromate formation is mainly attributed to the low initial bromide level of $33 \mu \mathrm{g} / \mathrm{L}$. Overall, the

538 formation of the potentially carcinogenic bromate was not an issue for ozonation of the selected

539 hospital wastewater.

540

541

\section{4. Conclusions}

543 - Combined information of chemical kinetics (ozone and ${ }^{\circ} \mathrm{OH}$ rate constants) and water specific

544 information (characterization of ozone and ${ }^{\circ} \mathrm{OH}$ exposures as a function of specific ozone dose) 
545 allows the prediction and generalization of the elimination efficiency of a large number of 546 structurally diverse micropollutants. This was successfully demonstrated in this study for a hospital 547 wastewater effluent from a MBR treatment.

548 - QSARs and the group contribution method were demonstrated to be useful in predicting ozone and

$549{ }^{\circ} \mathrm{OH}$ rate constants, respectively, for organic micropollutants without published rate constants.

$550-$ Measurements of ${ }^{\bullet} \mathrm{OH}$ exposure as a function of $\mathrm{gO}_{3} / \mathrm{gDOC}$ are recommended in the planning stage 551 of wastewater ozonation facilities for micropollutant elimination and can be conveniently 552 performed using laboratory batch elimination experiments for samples spiked with ${ }^{\circ} \mathrm{OH}$-probe 553 compounds (e.g., para-chlorobenzoic acid).

554 - Ozone exposure can be indirectly estimated using $\mathrm{O}_{3}$-probe compounds (e.g., carbamazepine or 555 bezafibrate) especially for low specific ozone doses. For more reliable measurements, direct 556 measurements from ozone decay curves are recommended.

557 - With increasing $\mathrm{pH}$ from 7.0 to 8.5 , the elimination levels increased for ozone-reactive compounds 558 with amine-moieties due to the higher ozone rate constants while decreased for most ozone559 resistant compounds due to the reduced ${ }^{\circ} \mathrm{OH}$ exposure caused by increased ${ }^{\bullet} \mathrm{OH}$ quenching rate by 560 effluent organic matter and carbonate with increasing $\mathrm{pH}$.

561 - The effect of $\mathrm{H}_{2} \mathrm{O}_{2}$ addition on micropollutant elimination efficiency during ozonation was slightly 562 beneficial for $\mathrm{pH} 7$ but led to a smaller removal at $\mathrm{pH} 8.5$ especially for some ozone-reactive 563 compounds due to a decreased ozone exposure.

564 - Two-thirds of the micropollutants (38 out of 56) present in the hospital wastewater effluent were 565 compounds containing ozone-reactive moieties such as phenols, anilines, activated aromatics, 566 amines and thioethers and could be efficiently eliminated at low specific ozone doses (e.g., $93 \pm 9 \%$ 567 at $\mathrm{gO}_{3} / \mathrm{gDOC}=0.5$ ). 
- Iodinated contrast media, which constituted $\geq 80 \%$ of the mass load in the selected hospital 569 wastewater effluent, were eliminated relatively inefficiently, e.g., $\sim 70 \%$ for $\mathrm{gO}_{3} / \mathrm{gDOC}=1.0$ for 570 iopromide, due to low ozone and ${ }^{\circ} \mathrm{OH}$ rate constant.

571

572

\section{Supporting Information}

574 Tables S1-S5 and Figures S1-S10 are available for further additional supplementary material and 575 data.

576

577

578

579

580

581

582

583

\section{Acknowledgements}

This study was supported by the Swiss Cantons AG, BE, BL, GE, SG, SH, SO, SZ, TG, VD, ZH, the Federal Office for Spatial Development (ARE), co-financed by the budget 2 of NRP in the framework of the InterReg IVB project PILLS, the Swiss Federal Offices for the Environment FOEN (07.0142.PJ/H163-1663 and 07.0142.PJ/I232-2755), and the Basic Science Research Program through the National Research Foundation of Korea (NRF-2012R1A1A1010985) funded by the Ministry of Science ICT \& Future Planning. The authors thank Elisabeth Salhi for laboratory assistance and measuring bromide and bromate.

\section{References}

Acero, J., von Gunten, U. 2001. Characterization of oxidation processes: ozonation and the AOP $\mathrm{O}_{3} / \mathrm{H}_{2} \mathrm{O}_{2}$. J. Am Water Works Assoc. 93, 90-100. 
590 Bader, H., Hoigné, J., 1981. Determination of ozone in water by the indigo method. Water Res. 15, $591 \quad 449-456$.

592 Bader, H., Sturzenegger, V., Hoigné, J. 1988. Photometric method for the determination of low 593 concentrations of hydrogen peroxide by the peroxidase catalyzed oxidation of N,N-diethyl-p594 phenylenediamine (DPD). Water Res. 22, 1109-1115.

595 Benner, J., Salhi, E., Ternes, T., von Gunten, U., 2008. Ozonation of reverse osmosis concentrate: 596 Kinetics and efficiency of beta blocker oxidation. Water Res. 42, 3003-3012.

597 Beier, S., Cramer, C., Koster, S., Mauer, C., Palmowski, L., Schroder, H. F., Pinnekamp, J., 2011. 598 Full scale membrane bioreactor treatment of hospital wastewater as forerunner for hot-spot 599 wastewater treatment solutions in high density urban areas. Water Sci. Technol. 63, 66-71.

600 Blanch, A. R., Caplin, J. L., Iversen, A., Kuehn, I., Manero, A., Taylor, H. D., Vilanova, X., 2003, 601 Comparison of enterococcal populations related to urban and hospital wastewater in various 602 climatic and geographic European regions. J. Appl. Microbiol. 94, 994-1002.

603 Buffle, M.O., Schumacher, J., Meylan, S., Jekel, M., von Gunten, U. 2006a. Ozonation and advanced 604 oxidation of wastewater: Effect of $\mathrm{O}_{3}$ dose, $\mathrm{pH}$, DOM and $\mathrm{HO}^{\circ}$-scavengers on ozone 605 decomposition and $\mathrm{HO}^{\bullet}$ generation. Ozone Sci. Eng. 28, 247-259.

606 Buffle, M.O., Schumacher, J., Salhi, E., Jekel, M., von Gunten, U. 2006b. Measurements of the 607 initial phase of ozone decomposition in water and wastewater by means of a continuous quench608 flow system: Application to disinfection and pharmaceutical oxidation. Water Res. 40, $609 \quad 1884-1894$.

610 Dodd, M.C., Buffle, M.O., von Gunten, U., 2006. Oxidation of antibacterial molecules by aqueous 611 ozone: Moiety-specific reaction kinetics and application to ozone-based wastewater treatment. 612 Environ. Sci. Technol. 40, 1969-1977. 
613 Dong, M.M., Mezyk, S.P., Rosario-Ortiz, F.L., 2010. Reactivity of effluent organic matter (EfOM)

614 with hydroxyl radical as a function of molecular weight. Environ. Sci. Technol. 44, 5714-5720.

615 Escher, B.I., Bramaz, N., Ort, C., 2009. Monitoring the treatment efficiency of a full scale ozonation 616 on a sewage treatment plant with a mode-of-action based test battery. J. Environ. Monitoring 11, $617 \quad 1836-1846$.

618 Flyborg, L., Bjorlenius, B., Persson, K. M., 2010. Can treated municipal wastewater be reused after 619 ozonation and nanofiltration? Results from a pilot study of pharmaceutical removal in Henriksdal 620

Gerrity, D., Gamage, S., Holady, J.C., Mawhinney, D.B., Quinones, O., Trenholm, R.A., Snyder, S.A., 2011. Pilot-scale evaluation of ozone and biological activated carbon for trace organic contaminants mitigation and disinfection, Water Res. 45, 2155-2165.

Gerrity, D., Gamage, S., Jones, D., Korshin, G.V., Lee, Y., Pisarenko, A., Trenholm, R.A., von Gunten, U., Wert, E.C., Snyder, S.A. 2012. Development of surrogate correlation models to predict trace organic contaminant oxidation and microbial inactivation during ozonation, Water Res. 46, 6257-6272.

Hoigné, J., 1998. Chemistry of aqueous ozone and transformation of pollutants by ozonation and advanced oxidation processes. In: Hrubec, J. (Ed.), The Handbook of Environmental Chemistry. Springer-Verlag, Berlin Heidelberg, pp. 83-141.

Hollender, J., Zimmermann, S.G., Koepke, S., Krauss, M., McArdell, C.S., Ort, C., Singer, H., von Gunten, U., Siegrist, H., 2009. Elimination of organic micropollutants in a municipal wastewater treatment plant upgraded with a full-scale post-ozonation followed by sand filtration. Environ. Sci. Technol. 43, 7862-7869. 
635 Huber, M.M., Canonica, S., Park, G.Y., von Gunten, U., 2003. Oxidation of pharmaceuticals during 636 ozonation and advanced oxidation processes. Environ. Sci. Technol. 37, 1016-1024.

637 Huber, M. M., Göbel, A., Joss, A., Hermann, N., Löffler, D., McArdell, C. S., Ried, A., Siegrist, H., 638 Ternes, T. A., von Gunten, U. 2005. Oxidation of pharmaceuticals during ozonation of municipal 639 wastewater effluents: A pilot study. Environ. Sci. Technol. 39, 4290-4299.

640 Huber, S.A., Balz, A., Abert, M., Pronk, W., 2011. Characterization of aquatic humic and non-humic 641 matter with size-exclusion chromatography-organic carbon detection-organic nitrogen detection 642 (LC-OCD-OND). Water Res. 45, 879-885.

643 Kovalova, L., Siegrist, H., Singer, H., Wittmer, A., McArdell, C.S., 2012. Hospital wastewater 644 treatment by membrane bioreactor: performance and efficiency for organic micropollutant 645 elimination. Environ. Sci. Technol. 46, 1536-1545.

646 Kovalova, L., Siegrist, H., von Gunten, U., Eugster, J., Hagenbuch, M., Wittmer, A., Moser, R., 647 McArdell, C.S., 2013. Elimination of micropollutants during post-treatment of hospital 648 wastewater with powdered activated carbon, ozone, and UV. Environ. Sci. Technol. 47, 78996497908.

650 Lange, F., Cornelissen, S., Kubac, D., Sein, M. M., von Sonntag, J., Hannich, C. B., Golloch, A., 651 Heipieper, H. J., Moeder, M., von Sonntag, C. 2006. Degradation of macrolide antibiotics by 652 ozone: A mechanistic case study with clarithromycin. Chemosphere 65, 17-23.

653 Lee, Y., von Gunten, U., 2010. Oxidative transformation of micropollutants during municipal 654 wastewater treatment: comparison of kinetic aspects of selective (chlorine, chlorine dioxide, 655 ferrate ${ }^{\mathrm{VI}}$, and ozone) and non-selective oxidants (hydroxyl radical). Water Res. 44, 555-566. 
656 Lee, Y., von Gunten, U., 2012. Quantitative structure-activity relationships (QSARs) for the 657 transformation of organic micropollutants during oxidative water treatment. Water Res. 46, $658 \quad 6177-6195$.

659 Lee, Y., Gerrity, D., Lee, M., Bogeat, A.E., Salhi, E., Gamage, S., Trenholm, R.A., Wert, E.C., 660 Snyder, S.A., von Gunten, U., 2013. Prediction of micropollutant eliminaiton during ozonation of 661 municipal wastewater effluents: use of kinetic and water specific information. Environ. Sci. 662 Technol. 47, 5872-5881.

663 Lipari, F., Swarin, S.J., 1982. Determination of formaldehyde and other aldehydes in automobile 664 exhaust with an improved 2,4-dinitrophenylhydrazine method. J. Chromatogr. 247, 297-306.

665 Lutze, H., 2005. Ozonung von Benzotriazolen. Bachelor Thesis, Universität Duisburg, Essen.

666 Macova, M., Escher, B.I., Reungoat, J., Carswell, S., Lee Chue, K., Keller, J., Mueller, J.F., 2010.

667 Monitoring the biological activity of micropollutants during advanced wastewater treatment with 668 ozonation and activated carbon filtration. Water Res. 44, 477-492.

669 Mahnik, S. N., Lenz, K., Weissenbacher, N., Mader, R. M., Fuerhacker, M., 2007. Fate of 5670 fluorouracil, doxorubicin, epirubicin, and daunorubicin in hospital wastewater and their 671 elimination by activated sludge and treatment in a membrane-bio-reactor system. Chemosphere $67266,30-37$.

673 Margot J., Kienle, C., Magnet, A., Weil, M., Rossi, L., de Alencastro, L.F., Abegglen, C., Thonney, 674 D., Chèvre, N., Schärer, M., Barry, D.A., 2013. Treatment of micropollutants in municipal 675 wastewater: ozone or powdered activated carbon? Sci. Total. Environ. 461-462, 480-498.

676 Mezyk, S.P., Neubauer, T.J., Cooper, W.J., Peller, J.R., 2007. Free-radical-induced oxidative and 677 reductive degradation of sulfa drugs in water: absolute kinetics and efficiencies of hydroxyl 678 radical and hydrated electron reactions. J. Phys. Chem. A 111, 9019-9024. 
679 Minakata, D., Li, K., Westerhoff, P., Crittenden, J., 2009. Development of a group contribution 680 method to predict aqueous phase hydroxyl radical $\left(\mathrm{HO}^{\circ}\right)$ reaction rate constants. Environ. Sci. 681 Technol. 43, 6220-6227.

682 Naik, D.B., Moorthy, P.N., 1995. Studies on the transient species formed in the pulse radiolysis of 683 benzotriazole. Radiat. Phys. Chem. 46, 353-357.

684 Nakada, N., Shinohara, H., Murata, A., Kiri, K., Managaki, S., Sato, N., Takada, H. 2007. Removal 685 of selected pharmaceuticals and personal care products (PPCPs) and endocrine-disrupting 686 687 chemicals (EDCs) during sand filtration and ozonation at a municipal sewage treatment plant. Water Res. 41, 4373-4382.

NDRL/NIST Solution Kinetics Database on the Web, A compilation of kinetics data on solutionphase reactions, available at http://kinetics.nist.gov/solution/.

Nöthe, T., Fahlenkamp, H., von Sonntag, C., 2009. Ozonation of wastewater: Rate of ozone consumption and hydroxyl radical yield. Environ. Sci. Technol. 43, 5990-5995.

Ort, C., Lawrence, M. G., Reungoat, J., Eaglesham, G., Carter, S., Keller, J., 2010. Determining the fraction of pharmaceuticals residues in wastewater originating from a hospital. Water Res. 44, $605-615$.

Oulton, R.L., Kohn, T., Cwiertny, D.M., 2010. Pharmaceuticals and personal care products in effluent matrices: A survey of transformation and removal during wastewater treatment and implications for wastewater management. J. Environ. Monitoring 12, 1956-1978.

Real, F. J., Javier Benitez, F., Acero, J. L., Sagasti, J. J. P., Casas, F., 2009. Kinetics of the chemical oxidation of the pharmaceuticals primidone, ketoprofen, and diatrizoate in ultrapure and natural waters. Ind. Eng. Chem. Res. 48, 3380-3388. 
Reinthaler, F. F., Posch, J., Feierl, G., Wuest, G., Haas, D., Ruckenbauer, G., Mascher, F., Marth, E., 2003. Antibiotic resistance of E. coli in sewage and sludge. Water Res. 37, 1685-1690.

Reungoat, J., Escher, B.I., Macova, M., Argaud, F.X., Gernjak, W., Keller, J. 2012. Ozonation and biological activated carbon filtration of wastewater treatment plant effluents. Water Res. 46, $863-872$.

Salhi, E., von Gunten, U., 1999. Simultaneous determination of bromide, bromate and nitrite in low $\mu \mathrm{g} / \mathrm{L}$ levels by ion chromatography without sample pretreatment. Water Res. 33, 3239-3244.

Staehelin, J., Hoigné, J., 1982. Decomposition of ozone in water: Rate of initiation by hydroxide ions and hydrogen peroxide. Environ. Sci. Technol. 16, 676-681.

Stalter, D., Magdeburg, A., Weil, M., Knacker, T., Oehlmann, J., 2010a. Toxication or detoxication? In vivo toxicity assessment of ozonation as advanced wastewater treatment with the rainbow trout. Water Res. 44, 439-448.

Stalter, D., Magdeburg, A., Oehlmann, J., 2010. Comparative toxicity assessment of ozone and activated carbon treated sewage effluents using an in vivo test battery. Water Res. 44, 2610-2620.

Verlicchi, P., Galletti, A., Petrovic, M., Barcelo, D., 2010. Hospital effluents as a source of emerging pollutants: An overview of micropollutants and sustainable treatment options. J. Hydrol. 389, $416-428$.

von Gunten, U., 2003a. Ozonation of drinking water: Part I. Oxidation kinetics and product formation. Water Res. 37, 1443-1467.

von Gunten, U., 2003b. Ozonation of drinking water: Part II. Disinfection and by-products formation in presence of bromide, iodide or chlorine. Water Res. 37, 1469-1487.

von Sonntag, C.; von Gunten, U. Chemistry of Ozone in Water and Wastewater Treatment: From Basic Principles to Applications; IWA Publishing: London, 2012. 
724 Weissbrodt, D., Kovalova, L., Ort, C., Pazhepurackel, V., Moser, R., Hollender, J., Siegrist, H., 725 McArdell, C., 2009. Mass flows of x-ray contrast media and cytostatics in hospital wastewater, 726 Environ. Sci. Technol. 43, 4810-4817.

727 Zimmermann, S.G., Wittenwiler, M., Hollender, J., Krauss, M., Ort, C., Siegrist, H., von Gunten, U., 728 2011. Kinetic assessment and modeling of an ozonation step for full-scale municipal wastewater 729 treatment: micropollutant oxidation, by-product formation and disinfection. Water Res. 45, $730 \quad 605-617$.

731 Zimmermann, S. G., Schmukat, A., Schulz, M., Benner, J., von Gunten, U., Ternes, T.A., 2012. 732 Kinetic and mechanistic investigations of the oxidation of tramadol by ferrate and ozone, 733 Environ. Sci. Technol. 46, 876-884.

734

735

736

737 
1 Table 1. Selected micropollutants and their second-order reaction rate constant with ozone and ${ }^{\bullet} \mathrm{OH}$.

\begin{tabular}{lcccc}
\hline \multirow{2}{*}{ compounds } & $k_{\mathrm{O} 3, \mathrm{pH} 7}{ }^{\mathrm{a}}$, & $k_{\mathrm{O} 3, \mathrm{pH} 8.5}{ }^{\mathrm{b}}$, & $k_{\mathrm{O} 3, \mathrm{ss}}{ }^{\mathrm{c}}$, & $k_{\bullet \mathrm{OH}}{ }^{\mathrm{d}}$, \\
& $\mathrm{M}^{-1} \mathrm{~s}^{-1}$ & $\mathrm{M}^{-1} \mathrm{~s}^{-1}$ & $\mathrm{M}^{-1} \mathrm{~s}^{-1}$ & $\mathrm{M}^{-1} \mathrm{~s}^{-1}$ \\
\hline
\end{tabular}

Group Ia: $k_{\mathrm{O} 3, \mathrm{pH} 7} \geq 1 \times 10^{4}$ and $k_{\mathrm{O} 3, \mathrm{pH} 8.5} \geq 1 \times 10^{4} \mathrm{M}^{-1} \mathrm{~s}^{-1}$

\begin{tabular}{|c|c|c|c|c|}
\hline Carbamazepine & $3 \times 10^{5}$ & $3 \times 10^{5}$ & $3 \times 10^{5 \mathrm{e}}$ & $8.8 \times 10^{9 \mathrm{e}}$ \\
\hline Clarithromycin & $4.0 \times 10^{4}$ & $9.6 \times 10^{5}$ & $4 \times 10^{6 f}$ & $\sim 5 \times 10^{9} \mathrm{~g}$ \\
\hline Diclofenac & $1 \times 10^{6}$ & $1 \times 10^{6}$ & $1 \times 10^{6 \mathrm{e}}$ & $7.5 \times 10^{9} \mathrm{e}$ \\
\hline Furosemide & $6.8 \times 10^{4}$ & $6.8 \times 10^{4}$ & $6.8 \times 10^{4 f}$ & $\sim 10^{10 \mathrm{~g}}$ \\
\hline Lidocaine & $7.3 \times 10^{4}$ & $3.9 \times 10^{5}$ & $1.1 \times 10^{4 \mathrm{~g}, \mathrm{~h}} / 4.5 \times 10^{5 \mathrm{~g}, \mathrm{i}}$ & $\sim 10^{10 \mathrm{~g}}$ \\
\hline Mefenamic acid & $6.4 \times 10^{6}$ & $6.4 \times 10^{6}$ & $6.4 \times 10^{6 \mathrm{~g}}$ & $\sim 10^{10 \mathrm{~g}}$ \\
\hline Ranitidine & $4.1 \times 10^{6}$ & $5.1 \times 10^{6}$ & $4.0 \times 10^{6 \mathrm{~g}, \mathrm{j}} / 1.7 \times 10^{6 \mathrm{~g}, \mathrm{i}}$ & $\sim 10^{10 \mathrm{~g}}$ \\
\hline Sotalol & $1.9 \times 10^{4}$ & $1.3 \times 10^{5}$ & $1.5 \times 10^{4 \mathrm{~g}, \mathrm{~h}} / 1.0 \times 10^{6 \mathrm{~g}, \mathrm{i}}$ & $\sim 10^{10 \mathrm{~g}}$ \\
\hline Sulfamethoxazole & $5.5 \times 10^{5}$ & $5.7 \times 10^{5}$ & $4.7 \times 10^{4 \mathrm{k}, \mathrm{l}} / 5.7 \times 10^{5 \mathrm{k}, \mathrm{m}}$ & $8.5 \times 10^{9 n}$ \\
\hline Sulfapyridine & $2.0 \times 10^{5}$ & $8.5 \times 10^{5}$ & $1.6 \times 10^{5 \mathrm{~g}, 1} / 1.6 \times 10^{6 \mathrm{~g}, \mathrm{~m}}$ & $8.2 \times 10^{9} \mathrm{~g}$ \\
\hline
\end{tabular}

Group Ib: $k_{\mathrm{O} 3, \mathrm{pH} 7}<1 \times 10^{4}$ and $k_{\mathrm{O} 3, \mathrm{pH} 8.5} \geq 1 \times 10^{4} \mathrm{M}^{-1} \mathrm{~s}^{-1}$

\begin{tabular}{lcccc}
\hline $\begin{array}{l}\text { 4-methyl- } \\
\text { benzotriazole }\end{array}$ & $7.8 \times 10^{2}$ & $1.1 \times 10^{4}$ & $3.1 \times 10^{2 \mathrm{~g}, 1} / 3.8 \times 10^{4 \mathrm{~g}, \mathrm{~m}}$ & $\sim 8.6 \times 10^{9 \mathrm{~g}}$ \\
Atenolol acid & $2.5 \times 10^{3}$ & $6.2 \times 10^{4}$ & $1.0 \times 10^{6 \mathrm{~g}, \mathrm{i}}$ & $\sim 10^{10 \mathrm{~g}}$ \\
Metoprolol & $2.0 \times 10^{3}$ & $5.1 \times 10^{4}$ & $8.6 \times 10^{5 \mathrm{o}, \mathrm{i}}$ & $7.3 \times 10^{9 \mathrm{o}}$ \\
Tramadol & $4.0 \times 10^{3}$ & $1.1 \times 10^{5}$ & $1.0 \times 10^{6 \mathrm{p}, \mathrm{i}}$ & $6.3 \times 10^{9 \mathrm{p}}$ \\
Venlafaxine & $8.5 \times 10^{3}$ & $1.5 \times 10^{5}$ & $3.2 \times 10^{3 \mathrm{~g}, \mathrm{~h}} / 1.3 \times 10^{6 \mathrm{~g}, \mathrm{i}}$ & $\sim 10^{10 \mathrm{~g}}$ \\
& & & & \\
\hline
\end{tabular}

Group II: $50 \leq k_{\mathrm{O} 3, \mathrm{pH} 7}$ and $k_{\mathrm{O} 3, \mathrm{pH} 8.5}<1 \times 10^{4} \mathrm{M}^{-1} \mathrm{~s}^{-1}$

\begin{tabular}{lcccc}
\hline N(4)-acetyl & $2.5 \times 10^{2}$ & $2.6 \times 10^{2}$ & $2.0 \times 10^{1 \mathrm{k}, 1} / 2.6 \times 10^{2 \mathrm{k}, \mathrm{m}}$ & $6.8 \times 10^{9 \mathrm{k}}$ \\
sulfamethoxazole & $2.4 \times 10^{2}$ & $2.3 \times 10^{3}$ & $3.5 \times 10^{3 \mathrm{q}, \mathrm{m}}$ & $7.6 \times 10^{9 \mathrm{r}}$ \\
Benzotriazole & $5.9 \times 10^{2}$ & $5.9 \times 10^{2}$ & $5.9 \times 10^{2 \mathrm{e}}$ & $7.4 \times 10^{9 \mathrm{e}}$ \\
Bezafibrate & $2.2 \times 10^{2}$ & $6.8 \times 10^{3}$ & $1.8 \times 10^{5 \mathrm{~g}, \mathrm{~m}}$ & $9.1 \times 10^{9 \mathrm{~g}}$ \\
Gabapentin & & & \\
\hline
\end{tabular}

Group III: $k_{\mathrm{O} 3, \mathrm{pH} 7}$ and $k_{\mathrm{O} 3, \mathrm{pH} 8.5}<50 \mathrm{M}^{-1} \mathrm{~s}^{-1}$ and $k_{\bullet \mathrm{OH}} \geq 5 \times 10^{9} \mathrm{M}^{-1} \mathrm{~s}^{-1}$ 


$\begin{array}{lcccc}\text { Oxazepam } & \sim 1 & \sim 1 & \sim 1^{\mathrm{g}} & 9.1 \times 10^{9 \mathrm{~g}} \\ \text { Primidone } & <10 & <10 & <10^{\mathrm{g}} & 6.7 \times 10^{9 \mathrm{~s}} \\ \text { Valsartan } & 38 & 38 & 38^{\mathrm{g}} & \sim 10^{10 \mathrm{~g}}\end{array}$

\begin{tabular}{lcccc}
\hline \multicolumn{4}{c}{ Group IV: $k_{\mathrm{O} 3, \mathrm{pH} 7}$ and $k_{\mathrm{O} 3 \mathrm{pH} 8.5}<50 \mathrm{M}^{-1} \mathrm{~s}^{-1}$ and $1 \times 10^{9}<k_{\bullet \mathrm{OH}}<5 \times 10^{9} \mathrm{M}^{-1} \mathrm{~s}^{-1}$} \\
\hline Fluconazole & $\sim 2$ & $\sim 2$ & $\sim 2^{\mathrm{g}}$ & $4.4 \times 10^{9 \mathrm{~g}}$ \\
Iopromide & $<0.8$ & $<0.8$ & $<0.8^{\mathrm{e}}$ & $3.3 \times 10^{9 \mathrm{e}}$ \\
Levetiracetam & $<1$ & $<1$ & $<1$ & $3.8 \times 10^{9 \mathrm{~g}}$ \\
\hline
\end{tabular}

1 a apparent $k$-value for the reaction of $\mathrm{O}_{3}$ at $\mathrm{pH} \mathrm{7,}$, apparent $k$-value for the reaction of $\mathrm{O}_{3}$ at $\mathrm{pH} 8.5$, $2{ }^{\mathrm{c}}$ species-specific $k$-value for the reaction of $\mathrm{O}_{3},{ }^{\mathrm{d}} k$-value for the reaction of ${ }^{\bullet} \mathrm{OH}$, ${ }^{\mathrm{e}}$ from Huber et al., 3 2003, ${ }^{\mathrm{f}}$ from Lange et al., 2006, ${ }^{\mathrm{g}}$ estimated in this study (SI, Table S3), ${ }^{\mathrm{h}} k_{\mathrm{O} 3}$-value for the substituted 4 benzene, ${ }^{\mathrm{i}} k_{\mathrm{O} 3}$-value for the amine, ${ }^{\mathrm{j}} k_{\mathrm{O} 3}$-value for the thioether, ${ }^{\mathrm{k}}$ from Dodd et al., $2006,{ }^{1} k_{\mathrm{O} 3}$-value 5 for the protonated species, ${ }^{\mathrm{m}} k_{\mathrm{O} 3}$-value for the deprotonated species, ${ }^{\mathrm{n}}$ from Mezyk et al., $2007,{ }^{\mathrm{o}}$ from 6 Benner et al., 2008, ${ }^{\mathrm{p}}$ from Zimmermann et al., 2012, ${ }^{\mathrm{q}}$ from Lutze et al., 2005, ${ }^{\mathrm{r}}$ from Naik et al., 1995 , 7 s from Real et al., 2009. 

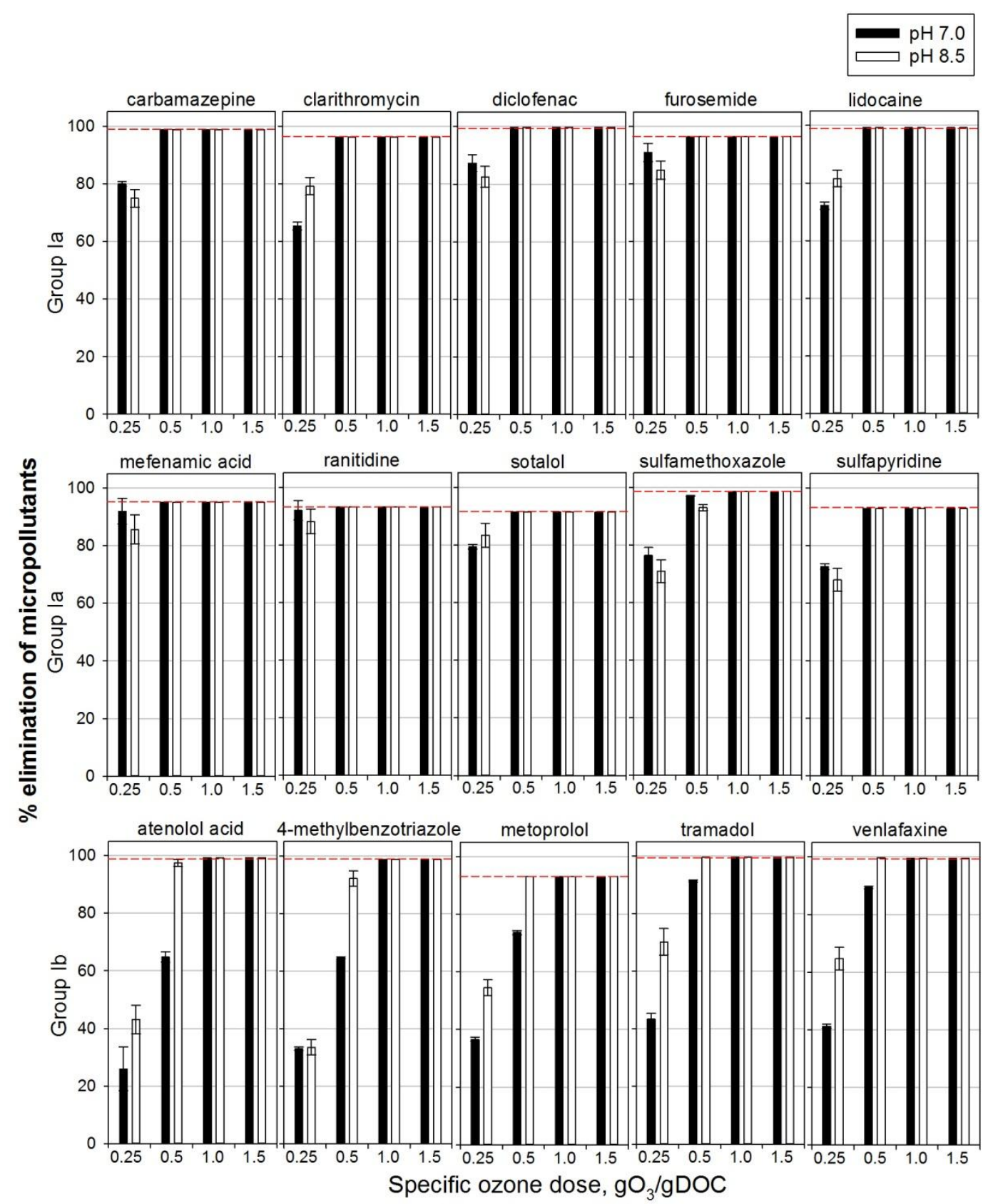

2 Figure 1. Elimination of group Ia (carbamazepine, clarithromycin, diclofenac, furosemide, lidocaine,

3 mefenamic acid, ranitidine, sotalol, sulfamethoxazole, and sulfapyridine) and group Ib (atenolol acid,

4 4-methyl-benzotriazole, metoprolol, tramadol, and venlafaxine) micropollutants as a function of the

5 specific ozone dose $\left(\mathrm{gO}_{3} / \mathrm{gDOC}\right)$ in a hospital wastewater effluent $(\mathrm{DOC}=5.1 \mathrm{mgC} / \mathrm{L})$. The dashed-

6 lines indicate the method quantification limit (LOQ) for \% elimination of micropollutants.

7 Experimental conditions: $\mathrm{pH}=7.0$ (filled bars) and 8.5 (empty bars), specific ozone doses

$8\left(\mathrm{gO}_{3} / \mathrm{gDOC}\right)=0.25,0.5,1.0$, and 1.5$)$, and $\mathrm{T}=22 \pm 2^{\circ} \mathrm{C}$. 

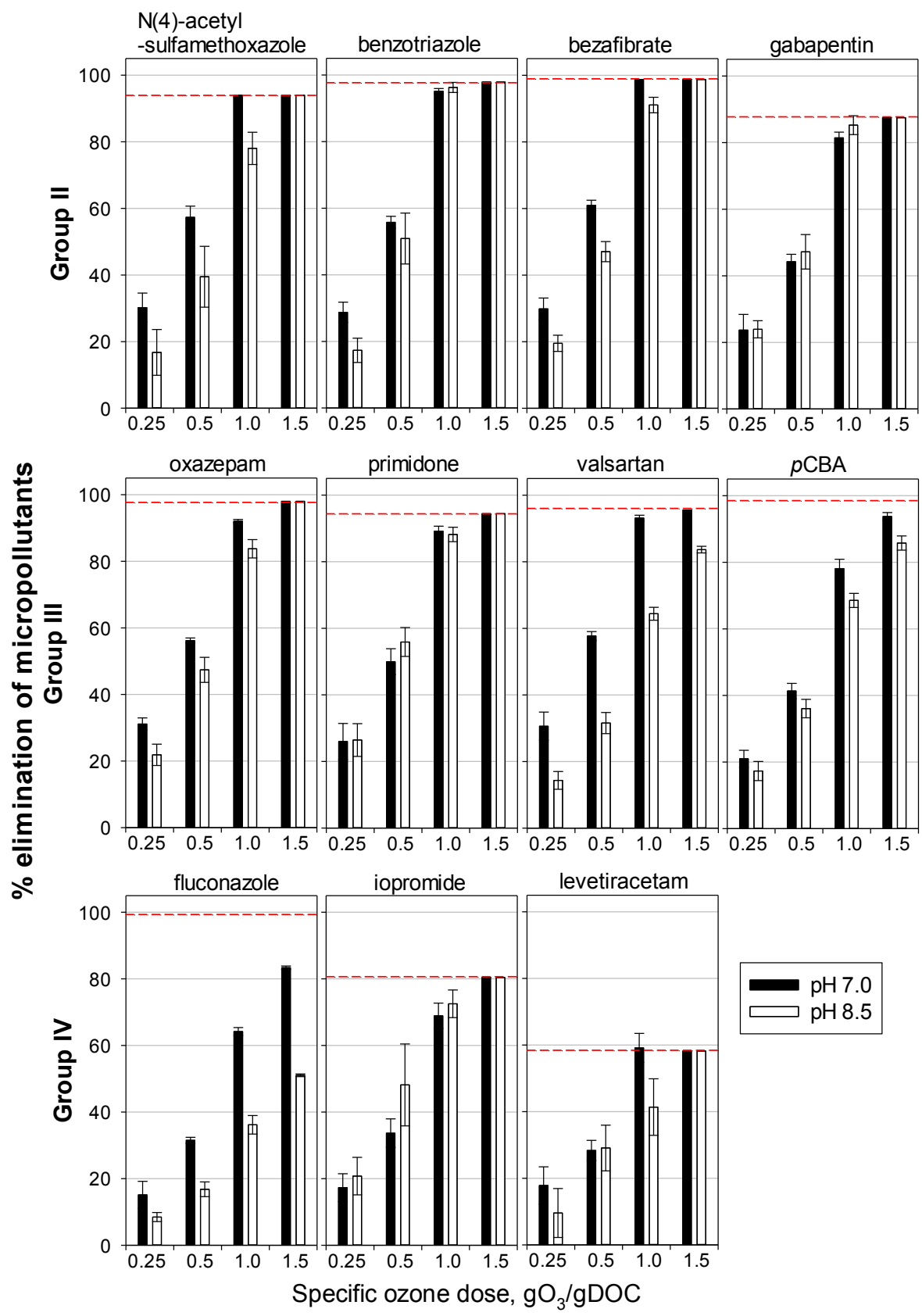

2 Figure 2. Elimination of group II (N(4)-acetylsulfamethoxazole, benzotriazole, bezafibrate, and 3 gabapentin), Group III (oxazepam, primidone, and valsartan), and group IV (fluconazole, iopromide, 4 and levetiracetam) micropollutants as a function of the specific ozone doses $\left(\mathrm{gO}_{3} / \mathrm{gDOC}\right)$ in a 5 hospital wastewater effluent. The dashed-lines indicate the method quantification limit (LOQ) for \% 6 elimination of micropollutants. Experimental conditions are the same as in Figure 1: $\mathrm{pH}=7.0$ (filled 7 bars) and 8.5 (empty bars). 

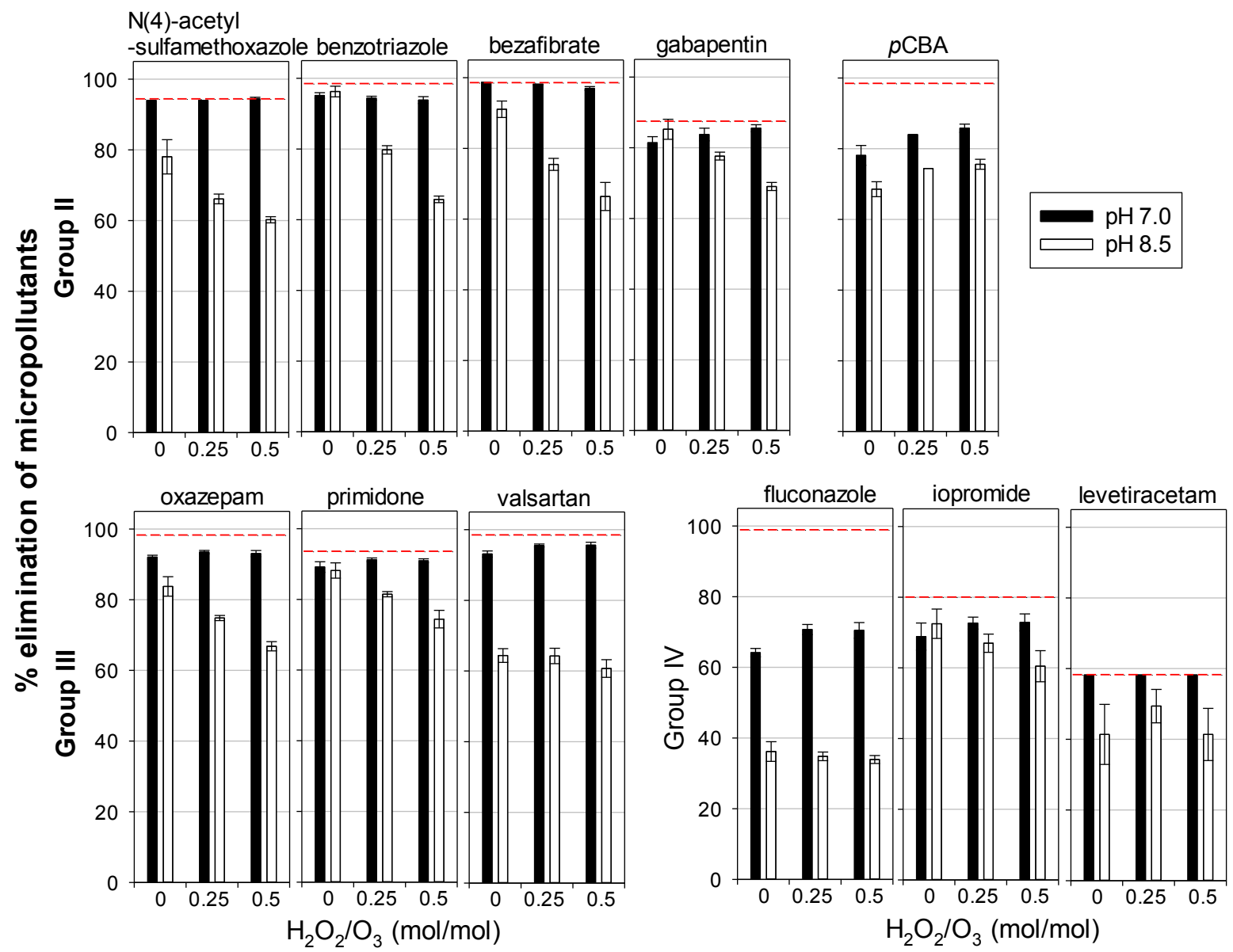

2 Figure 3. Effect of hydrogen peroxide addition on the elimination of group II, III, and IV during 3 ozonation of the hospital wastewater effluent at $\mathrm{pH} 7.0$ and 8.5. The applied specific ozone dose $4\left(\mathrm{gO}_{3} / \mathrm{gDOC}\right)$ was 1.0 and the $\mathrm{H}_{2} \mathrm{O}_{2} / \mathrm{O}_{3}$ ratio (mol $/ \mathrm{mol}$ ) was $0,0.25$ and 0.5 , respectively. The dashed5 lines indicate the method quantification limit (LOQ) for \% elimination of micropollutants. 6 Experimental conditions are the same as in Figure 1: $\mathrm{pH}=7.0$ (filled bars) and 8.5 (empty bars) 


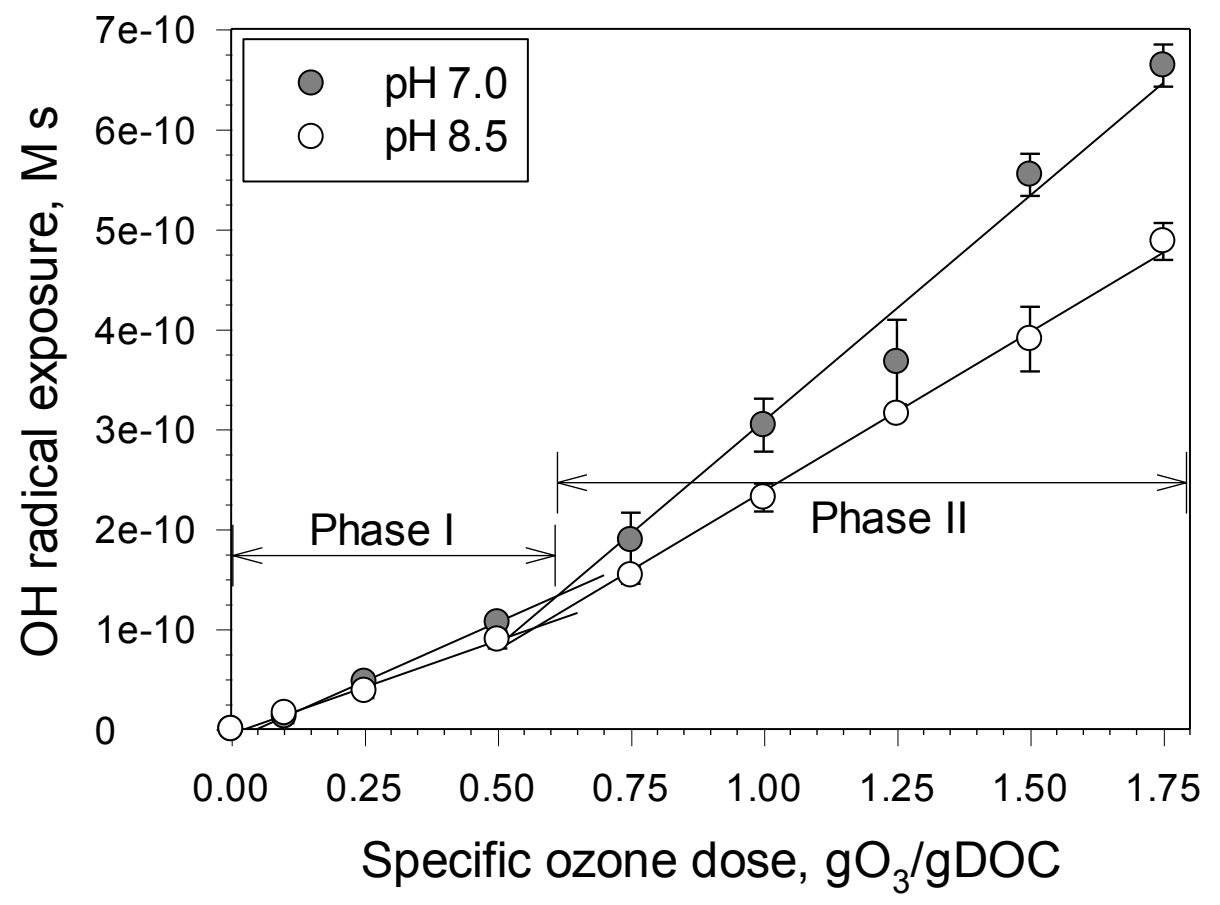

2 Figure 4. ${ }^{\circ} \mathrm{OH}$ exposure determined for various specific ozone doses $\left(\mathrm{gO}_{3} / \mathrm{gDOC}\right)$ at $\mathrm{pH} 7$ and 8.5 in 3 a hospital wastewater effluent $\left(\mathrm{DOC}=5.1 \mathrm{mgC} / \mathrm{L}\right.$ and $\left.\mathrm{T}=22 \pm 2^{\circ} \mathrm{C}\right) .{ }^{\circ} \mathrm{OH}$ exposures were calculated 4 from the decrease of $p$-chlorobenzoic acid $(p \mathrm{CBA})$ as ${ }^{\bullet} \mathrm{OH}$ probe compound. The lines represent 5 linear regressions of the experimental data for ${ }^{\circ} \mathrm{OH}$ exposure vs. $\mathrm{gO}_{3} / \mathrm{gDOC}$ (see text).

6

7

8

9

10

11

12 


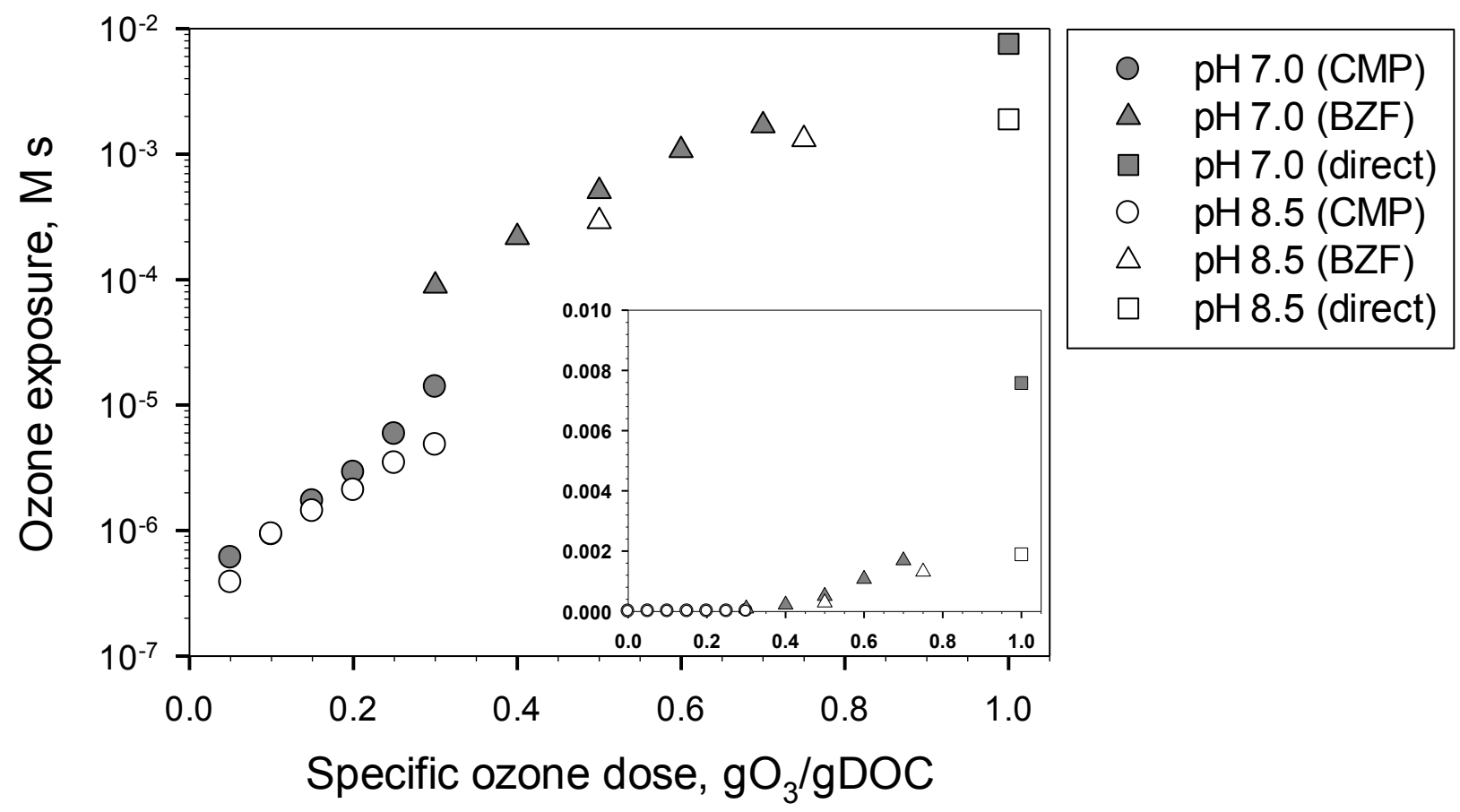

2 Figure 5. Ozone exposure determined for various specific ozone doses $\left(\mathrm{gO}_{3} / \mathrm{gDOC}\right)$ at $\mathrm{pH} 7$ and 8.5

3 in a hospital wastewater effluents ( $\mathrm{DOC}=5.1 \mathrm{mgC} / \mathrm{L}$ and $\mathrm{T}=22 \pm 2^{\circ} \mathrm{C}$ ). Ozone exposures were

4 calculated from the decrease of carbamazepine (CMP) for specific ozone doses of $0.05-0.3$, from

5 bezafibrate (BZF) for specific ozone doses of $0.3-0.7$, and from the area under the ozone decay

6 curves (direct). The main and inset figures show the ozone exposure in logarithmic and linear scales,

7 respectively.

8

9

10

11

12

13

14 

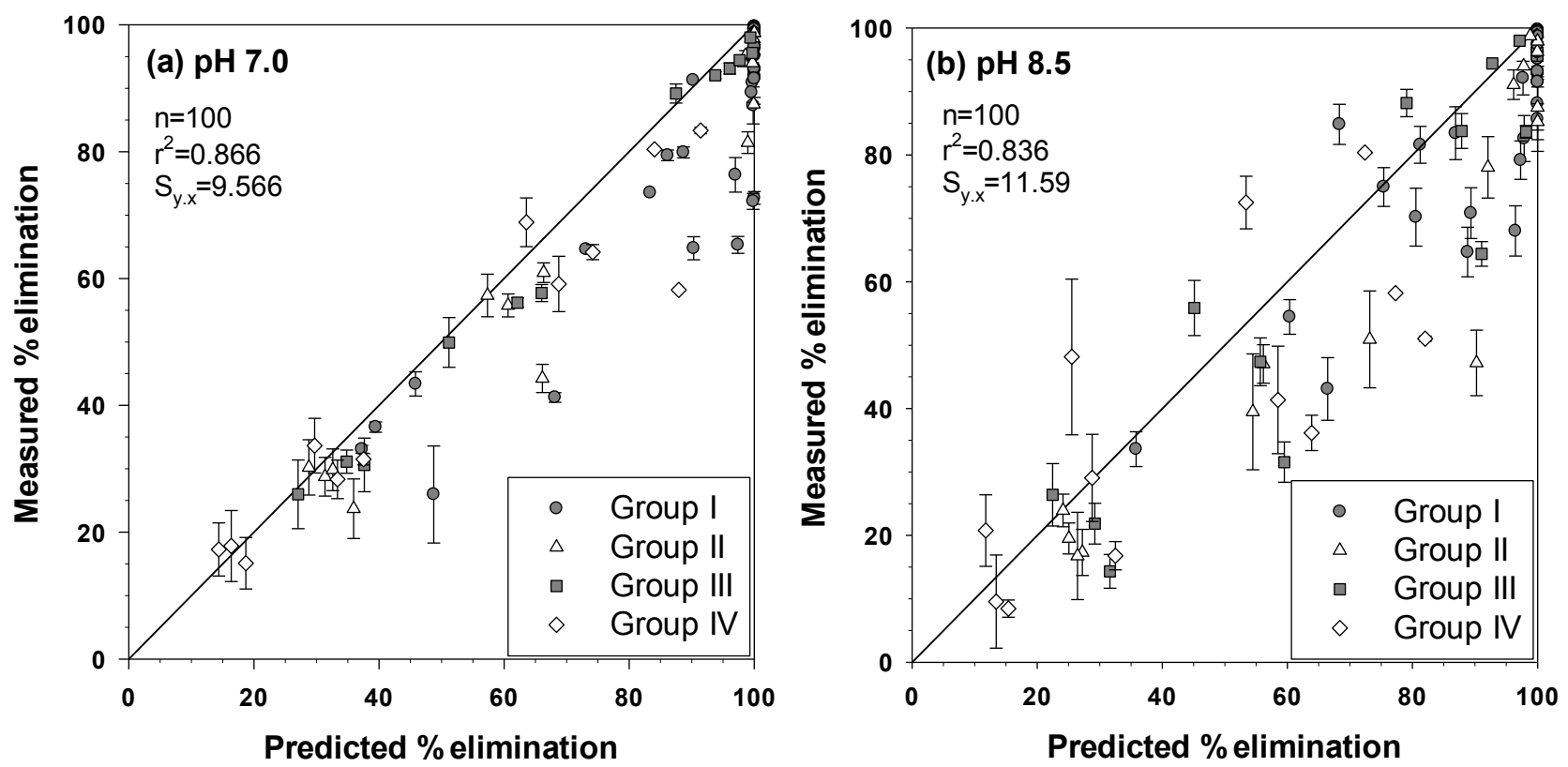

2 Figure 6. Measured and predicted \% elimination of the 25 micropollutants (Table 1) during hospital 3 wastewater effluent ozonation. (a) $\mathrm{pH} 7.0$ and (b) $\mathrm{pH} 8.5 \mathrm{n}$ is the number of data points $(=100)$ and $4 \quad \mathrm{~S}_{\mathrm{y} . \mathrm{x}}$ represents the standard deviation (or standard errors of estimate) of the linear regression with an 5 equation $\mathrm{y}=\mathrm{x}$ and is calculated as $(\mathrm{SS} / \mathrm{df})^{1 / 2}$ where $\mathrm{SS}$ is the sum-of-squares of the distance of the 6 linear regression from the data points $\left(\sum\left(\mathrm{Y}^{\prime}-\mathrm{Y}\right)^{2}\right)$ and $\mathrm{df}$ is the degree of freedom of the fit $(=\mathrm{n}-2=$ 7 98).

8 

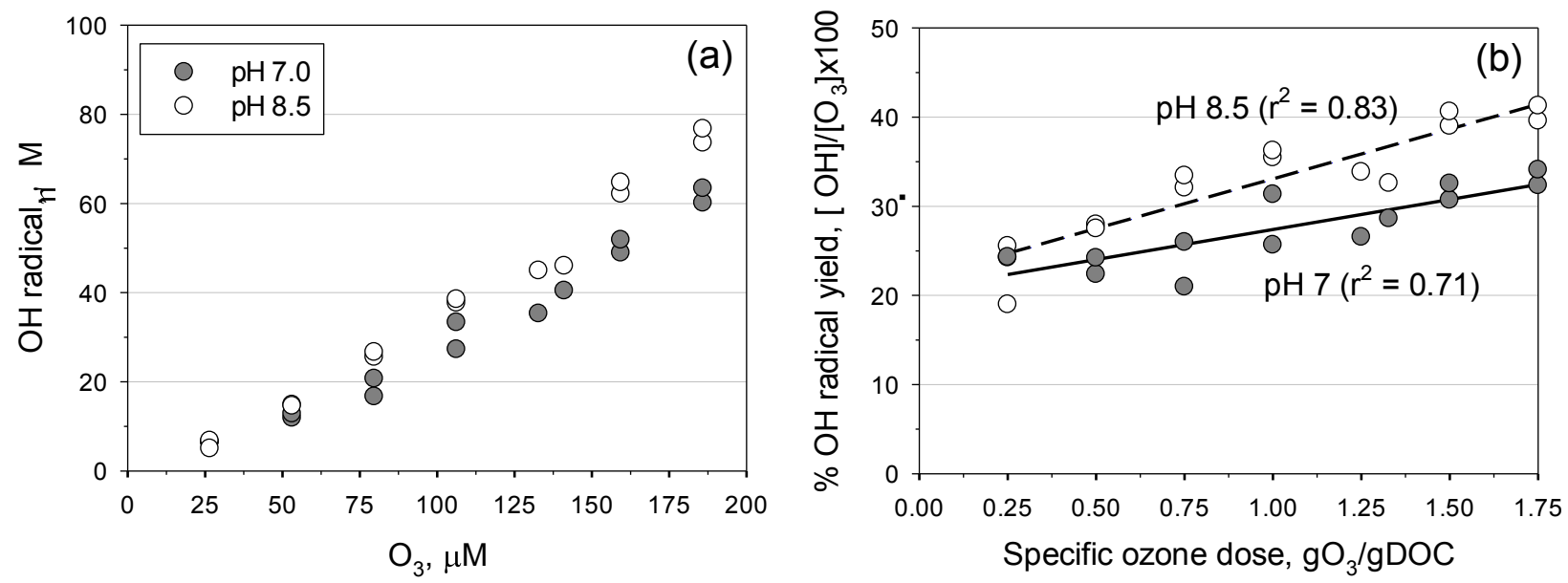

2 Figure 7. ${ }^{\circ} \mathrm{OH}$ formation during ozonation of hospital wastewater effluent at $\mathrm{pH} 7$ and 8.5. (a) ${ }^{\circ} \mathrm{OH}$

3 concentration as a function of ozone dose, and (b) $\%{ }^{\circ} \mathrm{OH}$ yield as a function of the specific ozone 4 dose $\left(\mathrm{gO}_{3} / \mathrm{gDOC}\right)$. The lines represent linear regressions of the data. The $\bullet \mathrm{OH}$ formation was 5 estimated from the concentration of $\mathrm{CH}_{2} \mathrm{O}$ formed in presence of excess tert-butanol $(10 \mathrm{mM})$ as an 6 •OH scavenger (Nöthe et al., 2009). 


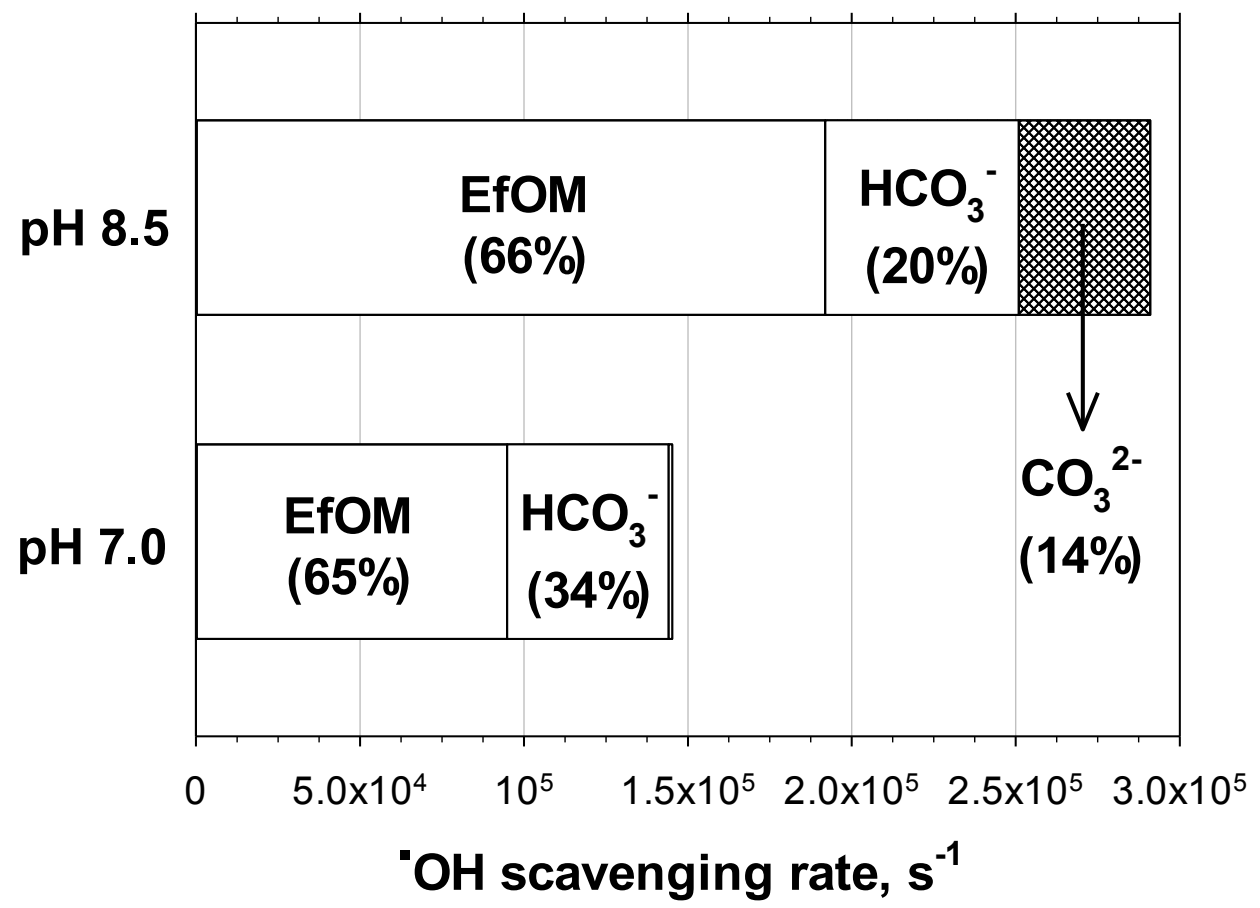

2 Figure $8 .{ }^{\bullet} \mathrm{OH}$ consumption rates during ozonation of a wastewater effluent at $\mathrm{pH} 7.0$ and $\mathrm{pH} 8.5$.

3 The $\%$ areas in the bars represent the relative ${ }^{\circ} \mathrm{OH}$ scavenging rate by EfOM and carbonate species

$4 \mathrm{HCO}_{3}{ }^{-}$and $\left.\mathrm{CO}_{3}{ }^{2-}\right)$. ${ }^{\circ} \mathrm{OH}$ scavenging rate was determined by using a competition kinetics method 5 employing tert-butanol as a competitor.

6

7

8

9

10

11 
- Elimination of micropollutants in hospital wastewater ozonation was well predicted.

- $\mathrm{O}_{3}$ and ${ }^{\bullet} \mathrm{OH}$ rate constants could be predicted by QSARs and group contribution method.

- $\mathrm{O}_{3}$ and ${ }^{\bullet} \mathrm{OH}$ exposures could be measured using proper $\mathrm{O}_{3}$ - and ${ }^{\bullet} \mathrm{OH}$-probe compounds.

- Most micropollutants in hospital wastewater effluent could be efficiently eliminated. 


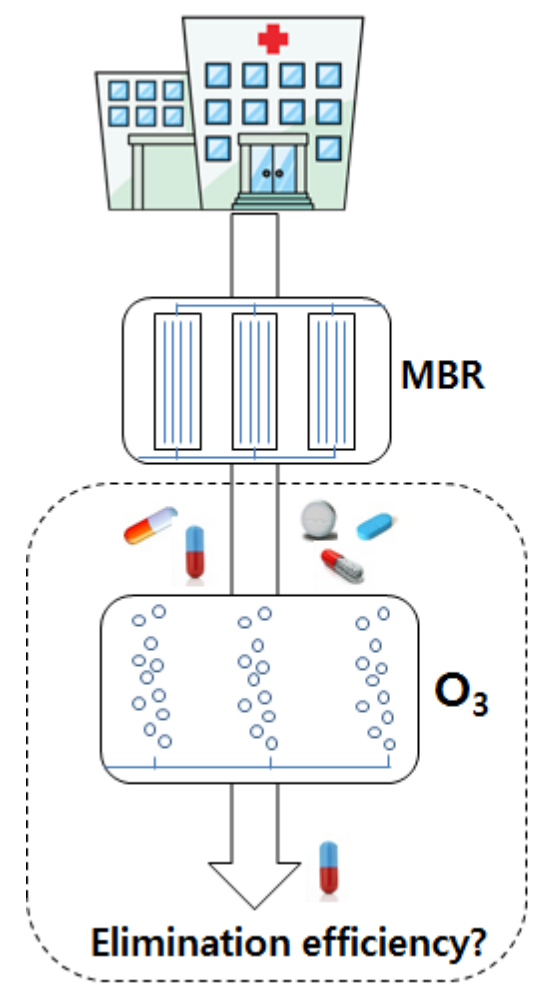

Chemical kinetics + water specific information

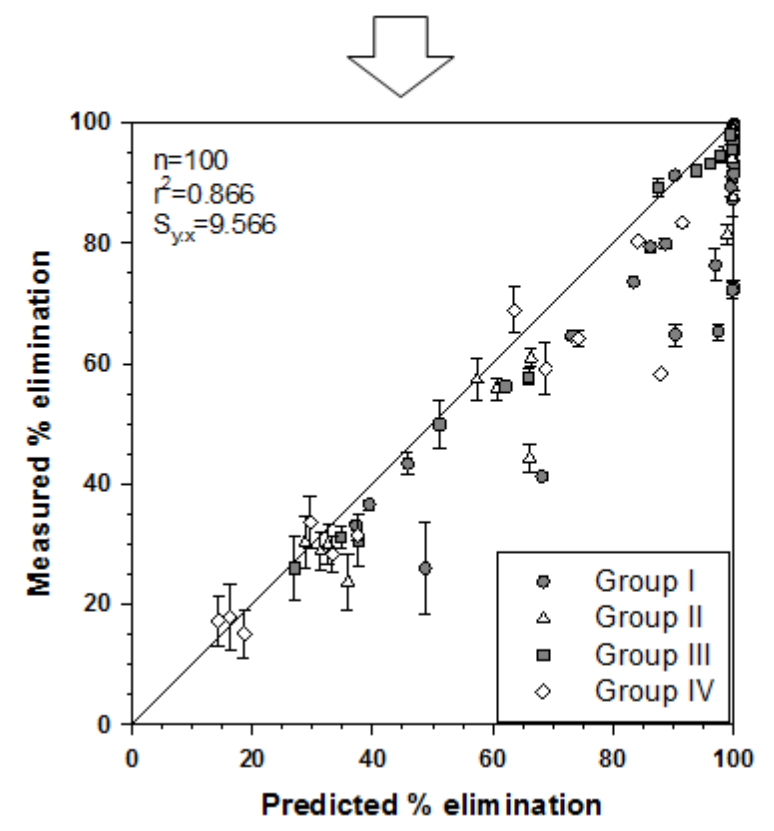

